\title{
Motivação e desempenho num curso de Simulação Empresarial
}

\author{
Margarida M. Pinheiro \\ Universidade de Aveiro, Portugal \\ Cláudia S. Sarrico \\ Universidade Técnica de Lisboa, Portugal
}

Rui A. Santiago

Universidade de Aveiro, Portugal

\begin{abstract}
Resumo
No sentido de melhorar o desempenho dos graduados no mercado de trabalho, foi desenvolvido, segundo uma metodologia tipo PBL, um curso de Simulação Empresarial num curso de contabilidade. $O$ foco deste trabalho centra-se na análise de qual o poder dos ambientes de aprendizagem inspirados em metodologias $\mathrm{PBL}$ nas motivações dos estudantes, e no entendimento de até que ponto a motivação influencia o seu desempenho. A investigação sugere que a presença de problemas profissionais reais envolvendo diferentes áreas de trabalho, a natureza inovadora da metodologia e as características pragmáticas da mesma, se constituem como elementos motivadores para os estudantes. Paralelamente, os mecanismos de feedback do trabalho realizado em conjunto com a oportunidade de reformulação dos erros cometidos assumem particular importância no entusiasmo e estímulo do estudante. $O$ efeito que a crescente motivação tem sobre as aprendizagens e, em última análise, sobre os resultados dos alunos, é um paradigma central do modelo.
\end{abstract}

Palavras-chave

Ensino superior; PBL; Motivação; Desempenho

\section{Introdução}

Sob a égide de uma intensa competição no mercado de trabalho e de uma crescente revolução social e económica, as instituições de ensino 
superior (IES) têm vindo a ser confrontadas com novas formas de produção e disseminação do conhecimento. Para fazer face aos novos problemas que se colocam ao ensino superior, numa perspectiva oposta a uma postura magistral de ensino, alguns autores insistem na ideia de que seria importante mudar as estratégias de ensino-aprendizagem, por forma a desenvolver competências que atravessem horizontalmente todo o currículo (Bayne, 2007; Kirschner, Vilsteren, Hummel, \& Wigman 1997; Tillema, Kessels, \& Meijers 2000; Rawson, 2000). Na concepção e desenvolvimento destas estratégias é possível recorrer a metodologias diferenciadas. Entre as diversas possibilidades destacamos as metodologias PBL (quer numa vertente de project-based learning, quer de problem-based learning). Partindo da apresentação de cenários contextualizados por situações profissionais reais, as metodologias PBL procuram enfatizar a mudança do paradigma do ensino para a aprendizagem através da responsabilização dos estudantes pelas suas próprias aprendizagens (Barrows, 1999; Kolmos, 1996).

O presente artigo foca-se na análise das formas como as mudanças inspiradas por metodologias PBL se repercutem nas motivações e consequentes desempenhos dos estudantes. Assim, a primeira expectativa da nossa investigação é tentar perceber o que torna os estudantes determinados na procura do saber como fazer inerente à sua futura profissão. A segunda expectativa é aumentar o entendimento sobre mecanismos motivacionais relacionados com ambientes de aprendizagem.

O presente artigo encontra-se organizado em quatro pontos fundamentais: no primeiro começamos por introduzir o contexto português de ensino profissionalizante e fazer uma breve descrição do modelo PBL; no segundo incluímos o contexto e o desenho do estudo de caso utilizado na investigação; o terceiro ponto é dedicado à apresentação dos resultados obtidos junto dos alunos, graduados e docentes e, no último ponto, apresentamos a discussão conducente às principais conclusões do estudo.

\section{0 contexto português de ensino-aprendizagem no ensino superior profissionalizante}

Por oposição à ideia conceptual de universidade como instituição em busca da verdade académica, formadora de elites intelectuais desponta, a 
partir da década de 50 e um pouco por toda a Europa, uma universidade de massas, aberta a novos públicos (Neave \& van Vught, 1994). Ao mesmo tempo que outros países buscavam novos caminhos para o ensino superior, seguindo uma via marcadamente profissionalizante, também Portugal não ficou de fora na procura de soluções para enfrentar os défices de desenvolvimento, em larga medida identificados com a falta de técnicos profissionais intermédios de que as actividades socioeconómicas careciam. Esta urgência em formar técnicos e quadros superiores impulsionou 0 alargamento da rede de ensino superior português que se desenvolveu num sistema binário, contemplando o ensino universitário e o ensino politécnico (Arroteia, 2002). Ainda que as linhas e os objectivos gerais das duas modalidades de ensino remontem a 1973, só a 26 de Dezembro, o DecretoLei 513T/79 institucionaliza formalmente o ensino superior politécnico. Neste documento é feita referência à simultaneidade das duas modalidades, acentuando a "tónica vincadamente profissionalizante" do ensino superior politécnico, por oposição a "características mais conceptuais e teóricas" do ensino superior universitário. Encontramos assim duas lógicas distintas: no ensino universitário e em tempos sequenciais, distinguimos o saber e o saber fazer, enquanto no ensino politécnico coincidem, num mesmo tempo, o saber, o saber fazer e o fazer. É neste contexto que se compreende o papel primordial das características regionais do ensino politécnico e a particular atenção que o mesmo presta às relações com as várias partes interessadas. De acordo com vários graus de intensidade, as questões de cooperação objectivam-se sob a forma de comprometimentos mútuos e especializados, revelando-se profícuo às IES repensar a formação dos seus estudantes adequando-a, o mais possível, às necessidades profissionais. De facto, aos futuros graduados compete, mais do que nunca, um papel socializador numa nova cultura de empresa, uma vez que os seus destinos ocupacionais serão, necessariamente, muito mais variados e difusos. E é o impacto destas ideias que faz reformular, mais do que o conceito de missão de ensino superior profissionalizante, a prática das instituições que o compõem.

Da simbiose de interesses que advêm da transferência de experiências entre o sistema educativo politécnico e o sistema produtivo empresarial, novas formas de ensino e aprendizagem são ponderadas, induzindo novos modelos de organização curricular. Autores como Silén \& 
Juhlin (2008) confirmam que as metodologias tradicionais se revelam inadequadas para o que precisa de ser sabido na educação profissional. As preocupações demonstradas com estas questões revelam-se na atenção dada à relação entre práticas pedagógicas e práticas profissionais. Para fortalecer esta posição, novas pedagogias centradas na aprendizagem dos estudantes têm vindo a revelar-se um importante paradigma metodológico. Uma forma possível de estabelecer a transição entre a prática educativa e a prática profissional é incentivar a mudança de um sistema tradicional de ensino para uma metodologia PBL.

\section{O modelo PBL}

Introduzido em finais dos anos sessenta e inicialmente associado a escolas de medicina, o modelo PBL tem vindo a ser desenvolvido nas mais variadas áreas e programas profissionais, recolhendo já mais de 30 anos de experiência. Não se centrando o presente trabalho na discussão das especificidades da metodologia, permitimo-nos uma apresentação sumária da mesma.

O conceito nuclear do paradigma PBL é o de um modelo organizacional capaz de promover a aquisição de conhecimento através de uma sequência contextualizada de problemas profissionais, identificados com situações reais que os estudantes futuramente integrarão. Tal conceito pressupõe a ideia de que conhecimento e competências são transferíveis de momentos anteriores para novas situações. Procurando dar corpo às mudanças que se encontram em curso nos processos de ensinoaprendizagem no ensino superior, o modelo PBL configura-se como um nó de uma rede onde se privilegia o pragmatismo, aprendizagens com significado, competências pessoais ou competências sociais.

Apesar da crescente utilização do paradigma PBL enquanto instrumento metodológico capaz de promover ambientes educacionais de aprendizagem no ensino superior (e.g. Albanese \& Mitchell, 1993; Musal, Taskiran, \& Kelson 2003), o modelo PBL suscita, no entanto, algumas inquietações (e.g. Major \& Palmer 2001). De facto, vários são os desafios propostos pela metodologia. Mas o problema das características específicas de avaliação, das vantagens e das desvantagens apontadas à utilização de 
teorias contextuais ou da (aparente) falta de controlo de aspectos cognitivos não são objecto de discussão no presente trabalho. Pelo contrário, o objecto de estudo da presente investigação é perceber como é que os estudantes que participaram em metodologias $\mathrm{PBL}$ perspectivam o impacto das mesmas nas suas motivações e consequentes desempenhos. Além disso, interrogamo-nos sobre a opinião dos docentes acerca desta temática.

De acordo com vários autores (e.g. de Vries, Schmidt, \& de Graaf 1989), é possível constatar que estudantes envolvidos em metodologias PBL reportam uma maior satisfação com as suas experiências de aprendizagem do que estudantes que nunca as utilizaram. Mas revisões mais finas da literatura também identificam um conjunto não negligenciável de estudantes que parecem não ter sucesso em ambientes PBL (Maclellan, 2008). Neste artigo procuramos prestar atenção a um leque variado de potenciais elementos motivadores. Para além dos tradicionalmente mencionados na literatura (pragmatismo, capacidade de aprender a aprender ou aprendizagem com significado), o nosso estudo expande-se para o conceito de autonomia, iniciativa, aprendizagem contínua, feedback dos trabalhos realizados ou avaliação entre pares.

Assim, tendo por base estes pressupostos, constituem-se como questões de investigação: (1) qual o poder dos ambientes de aprendizagem, nomeadamente os inspirados em metodologias PBL, nas motivações dos estudantes; e (2) até que ponto a motivação influencia o desempenho do estudante?

\section{O estudo de caso da Simulação Empresarial $O$ contexto}

A implementação da unidade curricular de Simulação Empresarial (inicialmente apelidada de Projecto Profissional) na Licenciatura em Contabilidade do Instituto Superior de Contabilidade e Administração da Universidade de Aveiro, ISCA-UA, remonta a 1997. O objectivo inicial era o de conjugar uma bagagem de conhecimentos teóricos adquiridos ao longo dos anos precedentes, com uma visão prática e integradora destes mesmos conhecimentos, tornando os futuros diplomados potencialmente mais aptos e vantajosamente competitivos para o exercício da futura profissão. 
Aproveitando a vontade da escola de proceder a uma reestruturação do curso e colocando de parte a ideia de introduzir um estágio curricular (o que correspondia a colocar profissionalmente cerca de 160 alunos por ano) surgiu a ideia de simular dentro da escola a realidade empresarial, com a criação de um mercado simulado de empresas virtuais. Nesta fase de arranque da unidade curricular, desejava-se não só complementar a formação inicial dos futuros diplomados através da integração dos currículos ministrados em anos anteriores do curso, como facultar a aplicação destes conhecimentos numa óptica profissional que aproximasse os futuros graduados do mundo empresarial onde se iriam integrar.

Assumindo-se a Simulação Empresarial como uma interface entre o meio académico e o meio profissional, o seu papel é o de catalisador motivacional da aprendizagem, num ambiente de simulação que pretende utilizar diferentes áreas de trabalho na promoção de uma perspectiva multidisciplinar. Entendida como síntese final, de natureza prática e interactiva, do conjunto de conhecimentos adquiridos pelos alunos ao longo do curso, a Simulação Empresarial pretende aproximar os futuros diplomados ao contexto empresarial, valorizando aptidões, atitudes e competências previamente identificadas com perfis idealizados. Pelas razões apontadas, a unidade curricular foi estrategicamente colocada no último semestre do plano curricular de estudos.

Após um período de inovação curricular em que a metodologia utilizada tinha por base um conjunto de competências que os alunos deviam adquirir no final do curso, os docentes envolvidos na disciplina começaram a sentir necessidade de se colocarem em contacto com outras experiências e modelos que pudessem dar contributos para a consolidação e aperfeiçoamento do trabalho até então realizado. A possibilidade surgiu com a realização de alguns workshops referentes a metodologias $P B L$ que tiveram lugar na Universidade de Aveiro, durante o ano 2000. Podendo a emergência de novas metodologias resultar de estratégias de push (a teoria impele a prática) ou de estratégias de pull (a prática impulsiona novos desenvolvimentos teóricos), sem sombra de dúvida, a necessidade prática sentida pelo ISCA-UA funcionou como uma teoria implícita.

Conforme já referimos, o objectivo inicial da disciplina era o de permitir aos estudantes experienciarem ambientes de aprendizagem próximos dos 
ambientes profissionais reais, utilizando técnicas e métodos de simulação. Para além deste objectivo genérico outros mais específicos foram igualmente definidos. Destes, destacamos: (1) consolidar e integrar o conhecimento adquirido em anos curriculares anteriores; (2) fornecer uma visão prática da profissão; e (3) permitir a aproximação entre a ética profissional e a ética empresarial. Complementarmente, outros objectivos podem ser referidos: (4) desenvolvimento da capacidade de trabalhar em equipa e sob pressão; (5) melhoria da expressão oral e escrita; (6) obtenção de uma visão global da actividade contabilística; e (7) capacidade de realizar análise crítica quer do próprio trabalho quer do trabalho dos pares.

$\mathrm{Na}$ unidade curricular de Simulação Empresarial é esperado que os estudantes, organizados em grupos de dois elementos, apliquem os conhecimentos e a informação obtida ao longo dos anos curriculares anteriores, na organização das empresas que ministram e que se encontram inseridas no mercado simulado de empresas virtuais.

Todos os alunos são gerentes ou sócios gerentes das empresas que possuem, devendo criar documentos que dão origem a registos contabilísticos, zelar pelo cumprimento das regras fiscais adequadas e tomar contacto com todo o género de formalismos e procedimentos com que se irão posteriormente deparar quando realmente integrados em empresas reais. No processo de reprodução fiel da realidade que simulam, é possível às empresas simuladas vender, comprar, receber, pagar, financiar ou recrutar pessoal, cabendo aos próprios alunos os papéis de gestores, contabilistas, directores financeiros ou técnicos comerciais das suas empresas virtuais, consoante indicações dos docentes responsáveis pela coordenação da Simulação Empresarial. Saliente-se que, o facto de ser o próprio aluno a ter de se introduzir no contexto em que vai decorrer o seu projecto específico, lhe confere um grau de dificuldade maior do que o que seria esperado num estágio numa empresa de base real, uma vez que, nesta situação, competiria à mesma o comando de todo o processo.

Ao promover-se a perspectiva da Simulação Empresarial como um culminar prático dos conhecimentos adquiridos ao longo do curso, não é indicada uma literatura específica, sendo que os alunos devem já conhecer a bibliografia adequada a cada tema. São sim fornecidas informações concretas de associações profissionais de contabilidade, fiscalidade ou auditoria, bem 
como endereços de sites específicos nas áreas de conhecimento envolvidas. A título exemplificativo, salientamos o sistema de normalização contabilístico, o plano oficial de contabilidade, as várias directrizes contabilísticas ou os códigos comerciais, fiscais ou do trabalho.

O número de grupos de alunos anualmente criado é, grosso modo, de 75. Cada grupo assume-se como empresa ou entidade pública, a quem é sorteada uma determinada actividade económica. Após o sorteio, e a partir de uma ficha inicial que fornece as linhas genéricas de enquadramento no mercado, cada grupo tem de proceder à constituição (ou reestruturação) da empresa, desempenhar todas as operações inerentes à actividade económica que desempenha e proceder ao fecho do período económico a que reporta, num espaço temporal correspondente a um ano civil. Paralelamente, é exigido o cumprimento de todas as operações legais associadas.

Actualmente, o mercado da Simulação Empresarial é constituído por empresas e entidades que representam mais de 30 sectores de actividade económica. Procurando responder às características regionais em que a IES se insere, o mercado virtual tem como sectores principais o sector das pescas e o sector da construção civil e obras públicas. À semelhança do mundo empresarial real, também o mercado virtual estabelece relações com agentes económicos a montante e a jusante contando, para o efeito, com o apoio de três entidades parceiras: a central pública, a central financeira e a central comercial. Enquanto a primeira desempenha o papel dos vários organismos públicos necessários ao funcionamento legal das empresas, a segunda tem o objectivo de assegurar e distribuir um conjunto diversificado de produtos e serviços financeiros. Por último, a central comercial enquadra e apoia a implementação da unidade curricular promovendo a dinâmica necessária ao funcionamento dos diversos sectores de actividade.

Apesar de incluído apenas no $6^{\circ}$ semestre do plano de estudos, a preparação da Simulação Empresarial começa durante o semestre lectivo imediatamente anterior ao do seu funcionamento. Durante este período, os docentes responsáveis pela coordenação da unidade curricular, definem o ramo e o número de empresas a incluir no mercado, bem como as respectivas estruturas particulares (número de trabalhadores, capital social mínimo, tipo de sociedade, mínimo de investimento ou tipo de empresa). Compete ainda à equipa de coordenação definir, desde início, o cronograma para cada ano lectivo e disponibilizar o regulamento específico da disciplina. 
$\mathrm{Na}$ Simulação Empresarial, é possível considerar empresas que transitam de anos anteriores e empresas que são criadas de raiz. No caso de empresas novas, cuja constituição será levada a cabo pelos alunos, será a coordenação quem fornece os elementos mínimos necessários ao seu funcionamento (número de empregados, capital inicial, ramo de actividade e outros). Se nos primeiros anos de implementação da disciplina muitas foram as empresas novas constituídas, nos anos seguintes a opção vai sobretudo no sentido de poderem ser utilizadas empresas provenientes de anos anteriores, circunstância que se prende com o facto de, no mundo real, poucos serem os alunos que conseguem constituir uma empresa de raiz.

No que se refere à utilização dos meios técnicos, dispõe a Simulação Empresarial de uma sala de trabalho própria, apetrechada com os recursos informáticos necessários ao seu funcionamento. De forma a melhorar a qualidade das aprendizagens e a valorizar a formação humana, a organização pro-activa em que assenta toda a disciplina, exige a utilização de software de uso corrente nas empresas. A comunicação entre os vários intervenientes do processo é feita recorrendo a um sistema de aprendizagem em e-learning que faz uso de uma plataforma específica de ensino à distância, onde se desenvolve a interactividade operacional de todo o sistema de simulação empresarial.

Antes do início das actividades operacionais e preparadas pela equipa de coordenação, são promovidas sessões de esclarecimento sobre temas de interesse geral para os alunos inscritos, e ministrados cursos de utilização dos vários programas informáticos disponíveis. Para além da equipa docente, são ainda recrutados alguns ex-alunos da disciplina, designados por monitores. As funções destes monitores são a de secretariar a coordenação e as centrais, sendo-Ihes definido um horário de trabalho remunerado, através de vínculo contratual. Para que o papel atribuído a esses monitores possa ser desempenhado da melhor forma, os mesmos recebem formação prévia, que inclui conhecimentos sobre o software a utilizar ou informação do modo de funcionamento dos recursos passíveis de utilização pelos alunos, não thes cabendo no entanto, qualquer função pedagógica.

É justo referir que a adopção de uma metodologia de simulação representou uma mudança significativa e um desafio acrescido quer para alunos quer para docentes. De facto, desenvolvendo-se a organização 
curricular do ISCA-UA segundo um modelo tradicional, os métodos utilizados na disciplina de Simulação Empresarial surgem isolados dos restantes recursos metodológicos do curso, impondo-se, abruptamente, a metodologias tradicionais. Como exemplo, mencione-se a mudança de uma metodologia expositiva para uma metodologia tutorial, ou a mudança de um sistema de avaliação tradicional baseado em exames escritos para uma avaliação contínua baseada em relatórios orais e consecução de objectivos profissionais.

Mais ainda, a componente de avaliação contínua do curso, utiliza processos de inspeç̧ão regular do trabalho realizado e permite ao docente, enquanto supervisor, avaliar a capacidade do aluno não só na resolução dos problemas propostos como no desempenho de múltiplas tarefas e funções essenciais à obtenção dos objectivos formulados. Nestas circunstâncias, os resultados esperados para as aprendizagens dos estudantes abrangem: (1) integração e aplicação de conhecimentos na resolução de problemas; (2) organização de informação; (3) preparação de relatórios; (4) trabalho de equipa; (5) realização atempada de tarefas; e (6) exposição oral. Para atingir tais objectivos, a avaliação apoia-se em debates quer entre estudantes quer destes com a equipa docente, apoia-se na observação do trabalho dos alunos, nas auditorias e fiscalizações periodicamente realizadas, apoia-se nas apresentações e portfolios que se realizam, bem como num vasto conjunto de outros elementos especificados para o efeito.

No processo de simulação vários docentes são envolvidos, cabendo a cada um a responsabilidade pela tutoria de um determinado número de grupos. Reuniões semanais entre docentes permitem estabelecer um ponto de situação e consequente regulação global da metodologia, sendo intuito geral que os estudantes assumam um crescente grau de responsabilidade na consecução das suas próprias metas de aprendizagem.

De acordo com vários autores (e.g. Frank \& Barzilai, 2004) uma aprendizagem com significado reside mais no fazer do que no saber fazer. A convicção da necessidade de avaliar um vasto conjunto de resultados de aprendizagem e o convencimento de que a avaliação devia incluir, também, elementos menos palpáveis presentes ao longo de todo o processo (e não apenas enfatizar o resultado final) conduziu a equipa docente à opção por uma avaliação (essencialmente) formativa. Donde podemos afirmar que, no 
caso particular da disciplina de Simulação Empresarial, o sistema de avaliação adoptado foi mais inspirado em boas práticas do que na literatura.

A importância atribuída à unidade curricular é confirmada pela Ordem do Técnicos Oficiais de Contas (OTOC) sendo o ISCA-UA uma das IES dispensadas do estágio exigido pela dita Ordem para acesso à inscrição como técnico oficial de contas. Tendo o estágio a finalidade tripla de proporcionar experiência profissional, de possibilitar uma maior articulação entre a instituição formadora e o mundo do trabalho, e de complementar as competências sócio-profissionais, na visão da OTOC, a Simulação Empresarial satisfaz os objectivos visados com um estágio tendo, por este facto, um valor acrescido para a profissão dos futuros graduados (Ordem dos Técnicos Oficiais de Contas, 2010).

Paralelamente, o carácter inovador da unidade curricular bem como o reconhecimento da OTOC tem também cativado outras instituições congéneres, daí resultando a implementação do modelo de simulação empresarial proposto pelo ISCA-UA noutras IES.

\section{O estudo de caso}

Os resultados apresentados neste estudo e que analisam as percepções dos estudantes, graduados e docentes sobre as motivações e desempenhos dos alunos, incluem-se numa investigação mais alargada sobre metodologias PBL em ambientes simulados no ensino superior profissionalizante De acordo com a literatura (Yin, 1994) o estudo fez uso de uma triangulação de elementos conducente a uma maior riqueza de pontos de vista: triangulação de dados (são analisadas as representações dos alunos, docentes e graduados), triangulação de teorias (o quadro teórico desenvolvido abarcou diferentes linhas orientadoras) e triangulação de métodos (são articuladas metodologias qualitativas e quantitativas).

Em particular e no que respeita à metodologia, a presente investigação elegeu os instrumentos da entrevista semi-estruturada aos docentes e do questionário aos restantes participantes.

\section{Entrevistas}

As entrevistas, realizadas em 2005, foram desenhadas para apreender as perspectivas dos académicos sobre as motivações e desempenhos dos 
alunos. Com o conhecimento prévio dos participantes, todas as entrevistas foram gravadas e transcritas para ficheiro informático. A estruturação dos guiões que serviram de fio condutor assentou no trabalho previamente desenvolvido durante a análise documental, na revisão da literatura e no conjunto de hipóteses de investigação formuladas. No contexto desta opção, os guiões tiveram por base um conjunto de questões abertas, assumidas mais como pontos de referência capazes de desencadearem discursos sobre possíveis efeitos da metodologia da Simulação Empresarial, do que como estruturas inflexíveis a seguir (Miles \& Huberman, 1994). Relativamente aos processos de tratamento dos dados obtidos nas entrevistas aos docentes, recorremos à análise de conteúdo, usando como suporte o programa informático QSR NUD*IST (Non-numerical Unstructured Data Indexing Searching and Theorizing).

Após uma análise prévia dos docentes envolvidos na disciplina desde a sua formação, optámos por incluir na amostra todos os elementos da população com, pelo menos, 4 anos de experiência com a metodologia da Simulação Empresarial, sendo que todos estes docentes incluíam os elementos da coordenação. Com base nestes critérios, o total de entrevistas realizadas foi de 14 .

\section{Questionários}

O estudo empírico respeitante aos estudantes e graduados baseou-se em questionários desenhados em ordem a apreender as percepções dos respondentes acerca da sua avaliação sobre a forma como as estratégias metodológicas utilizadas no curso moldaram as suas próprias motivações e subsequentes desempenhos. Tomando como ponto de partida o estado da arte e as questões de investigação enunciadas, desenvolveu-se o modelo dos questionários fechados ministrados ao grupo dos alunos e ao grupo dos diplomados. De uma forma global, as dimensões sobre o tema das motivações e o tema dos desempenhos foram muito semelhantes entre os dois grupos, com excepção da questão relativa à ligação entre a teoria e a prática que, pela sua especificidade só foi apresentada aos diplomados. Igualmente por razões que se prendem com os papéis representados pelos dois grupos, o questionário dos alunos incluiu uma dimensão relativa à avaliação (ver anexos 1 e 2). 
A forma de organização dos questionários procurou minimizar quer os riscos de pré-estruturação dos discursos quer a possibilidade do efeito de halo, e a validação dos mesmos teve por base amostras representativas de estudantes e de graduados. Foi também garantido o anonimato. Para além destes factores, os itens foram diferenciados entre escalas de opinião tipo Likert e perguntas factuais de resposta dual (sim e não). A configuração final dos questionários foi estruturada por forma a que fosse possível a sua leitura óptica. O tratamento dos dados obtidos foi realizado utilizando o pacote estatístico SPSS (Statistical Package for Social Sciences).

Podemos dizer que a amostra dos alunos se seleccionou a ela própria, dado que todos os estudantes inscritos na disciplina no momento em que decorreu a parte empírica desta investigação, foram incluídos na análise. Ponderadas diversas situações, optou-se pelo preenchimento não presencial do questionário. De um total de 138 alunos inscritos recolheram-se 132, o que corresponde a uma taxa de respostas de cerca de $95.6 \%$. A aplicação dos questionários decorreu durante Junho de 2004.

À semelhança dos alunos, o estudo incluiu todos os graduados que frequentaram o curso de Simulação Empresarial desde a sua criação. Os dados recolhidos cobriram o período de 1997 a 2004 e retornaram em 881 graduados. A administração dos questionários aos diplomados foi feita via CTT, juntamente com um envelope sem franquia, de modo a maximizar as possibilidades de resposta. O número de inquéritos recolhidos foi de 423 , correspondendo a uma taxa de respostas válidas de cerca de $48 \%$. A administração do questionário aos diplomados decorreu entre Fevereiro e Março de 2005.

\section{Resultados relativos a motivações e desempenhos}

Como ponto prévio a toda a discussão, refira-se que quer estudantes, quer docentes, quer graduados tendem a comparar as suas experiências PBL da disciplina de Simulação Empresarial com as experiências que Ihes são mais familiares em termos de metodologias de ensino-aprendizagem, ou seja, com experiências de cariz tradicional. Portanto, todas as conclusões que deste estudo possam advir devem ser vistas à luz da dualidade metodologias $\mathrm{PBL}$ versus metodologias tradicionais. 


\section{A perspectiva dos alunos}

Das respostas dadas na primeira parte do questionário ministrado aos estudantes, parece ser consenso geral que a investigação replica os modelos teóricos desenvolvidos para metodologias PBL em ambientes simulados (ver Quadro 1).

Quadro 1 - Caracterização dos resultados percentuais dos alunos em termos de motivações e desempenhos

\begin{tabular}{lccc}
\hline & $\begin{array}{c}\text { Em desacordo/ } \\
\text { parcialmente em } \\
\text { desacordo }\end{array}$ & $\begin{array}{c}\text { Nem de acordo } \\
\text { nem em } \\
\text { desacordo }\end{array}$ & $\begin{array}{c}\text { De acordo/ } \\
\text { parcialmente de } \\
\text { acordo }\end{array}$ \\
\hline $\begin{array}{l}\text { A metodologia encoraja a minha } \\
\text { autonomia }\end{array}$ & 10.6 & 17.6 & 71.8 \\
$\begin{array}{l}\text { A metodologia motiva-me para uma } \\
\text { aprendizagem continua }\end{array}$ & 10.7 & 14.5 & 74.8 \\
$\begin{array}{l}\text { A metodologia permite-me reconhecer } \\
\text { que a aprendizagem nấ é apenas } \\
\text { adquinir conhecimento mas passa } \\
\text { também pelo próprio processo de o } \\
\text { adquinir }\end{array}$ & 13.0 & 10.7 & 76.3 \\
\begin{tabular}{l} 
A metodologia estimula a mirha iniciativa \\
\hline
\end{tabular} & 13.7 & 13.7 & 72.6 \\
\hline
\end{tabular}

Os resultados evidenciam que, para uma larga percentagem de estudantes (superior a 72\%), a experiência da Simulação Empresarial parece desenvolver competências como autonomia, aprendizagem contínua, iniciativa e, principalmente, reconhecimento de que a aprendizagem não passa apenas pela acumulação factual do conhecimento mas também pelo próprio processo de o adquirir. No entanto, esta não é uma visão universal e uma análise mais fina mostra que vários estudantes manifestam apreensões com estes mesmos itens. Neste ponto e mais uma vez, remetemo-nos para o facto incontornável da Simulação Empresarial ser o primeiro contacto dos estudantes com uma estratégia PBL, por si só portadora de novos desafios de aprendizagem.

Socorrendo-nos da segunda parte do questionário é possível identificar algumas assunções relativas ao processo de avaliação associado a uma metodologia PBL. O Quadro 2 sumaria os resultados obtidos neste trecho. 


\section{Quadro 2 - Caracterização dos resultados percentuais dos alunos em} termos de avaliação

\begin{tabular}{lcc}
\hline & Sim & Não \\
\hline $\begin{array}{l}\text { O processo de avaliaçăo permite-me identificar quais os } \\
\text { objectivos da aprendizagem }\end{array}$ & 59.4 & 40.6 \\
$\begin{array}{l}\text { O processo de avaliaçäo fornece-me mecanismos de } \\
\text { feedback sobre o meu trabaho, a partir da equipa docente }\end{array}$ & 56.6 & 43.4 \\
$\begin{array}{l}\text { Esta oportunidade permite-me melhorar o meu } \\
\text { desempenho no sentido de melhor se ajustar aos } \\
\text { objectives esperados }\end{array}$ & 91.8 & 8.2 \\
\hline
\end{tabular}

Mesmo que a maioria dos estudantes exprima a posição de que a avaliação permite a identificação dos objectivos esperados para a aprendizagem, não podemos descurar que quase $41 \%$ dos alunos não reconhece à metodologia a capacidade de identificar, claramente, quais os resultados da aprendizagem que se pretende que adquiram no final do processo. As respostas dadas permitem traçar um retrato idêntico no que respeita à possibilidade do processo de avaliação da metodologia fornecer feedback que permita ao aluno reorientar o seu trabalho no sentido pretendido. Esta variabilidade de opiniões pode ser considerada como uma consequência resultante do facto do curso se desenvolver (inesperadamente) numa metodologia não tradicional. De particular interesse nos parece a posição dos estudantes que reconhecem que os mecanismos de reorientação do seu trabalho se tornaram elementos cruciais na melhoria dos resultados esperados. Tal facto parece sugerir um avanço na capacidade dos estudantes perseguirem os seus objectivos, orientados pelos mecanismos de retorno associados à metodologia PBL da Simulação Empresarial.

\section{A perspectiva dos graduados}

Numa perspectiva mais macro, os inquéritos aos graduados permitemnos realçar duas asserções: a convicção de que a aprendizagem não se traduz no simples acumular de conhecimento, mas também no próprio processo de o adquirir, e a identificação de que a metodologia PBL estimula a conexão entre a teoria e a prática (ver Quadro 3). 
Quadro 3 - Caracterização dos resultados percentuais dos graduados em termos de motivações e desempenhos

\begin{tabular}{lccc}
\hline & $\begin{array}{c}\text { Em desacordo/ } \\
\text { parcialmente em } \\
\text { desacordo }\end{array}$ & $\begin{array}{c}\text { Nem de acordo } \\
\text { nem em } \\
\text { desacordo }\end{array}$ & $\begin{array}{c}\text { De acordo/ } \\
\text { parcialmente de } \\
\text { acordo }\end{array}$ \\
\hline $\begin{array}{l}\text { A metodologia encoraja a minha } \\
\text { autonomia }\end{array}$ & 11.6 & 20.4 & 68.0 \\
$\begin{array}{l}\text { A metodologia motiva-me para uma } \\
\text { aprendizagem contínua }\end{array}$ & 9.7 & 12.5 & 77.8 \\
$\begin{array}{l}\text { A metodologia permite-me reconhecer } \\
\text { que a aprendizagem nāo é apenas } \\
\text { adquirir conhecimento mas passa } \\
\text { também pelo próprio processo de o } \\
\text { adquirir }\end{array}$ & 8.0 & 6.0 & 86.0 \\
$\begin{array}{l}\text { A metodologia estimula a minha iniciativa } \\
\text { A metodologia encoraja-me a relacionar a } \\
\text { teoria com a prática }\end{array}$ & 12.3 & 20.0 & 67.7 \\
\hline
\end{tabular}

Apesar das percepções dos graduados se ajustarem aos critérios teóricos associados a metodologias PBL, uma análise mais fina mostra que há uma maior amplitude de opiniões quando comparadas com as percepções emanadas pelos estudantes. Tal significa que os diplomados que manifestam uma atitude positiva em relação à utilização de metodologias $\mathrm{PBL}$ parecem ser mais receptivos a valorizar os mecanismos do processo de ensinoaprendizagem e a compreender a relação entre a teoria e a prática. Simultaneamente, são estes mesmos graduados que menos valorizam os efeitos da metodologia no campo da autonomia e da iniciativa.

\section{A perspectiva dos docentes}

A análise qualitativa a que submetemos os dados recolhidos junto dos docentes pode ser organizada em torno de quatro factores que consideramos essenciais.

Uma primeira posição engloba os paradigmas da autonomia, da forma de produção do conhecimento e da familiaridade dos estudantes com o seu futuro ambiente profissional. Não sendo uma relação tout court, a produção de conhecimento é descrita como um dos aspectos mais importantes da metodologia. Eis um exemplo destes testemunhos: 
O aspecto mais importante era realmente aprender isto mas aprender a aprender. Isto é, cada vez que fossem confrontados com uma situação nova, saber partir do que já sabem fazer, do que aprenderam, para aprender (Docente $\mathrm{K})$.

A partir dos discursos de vários docentes é possível acentuar o aprender a aprender e as experiências pré-profissionais como elementos motivadores de uma aprendizagem mais autónoma e proactiva. Um dos comentários revela:

Eles já são mais seguros das ideias e dos problemas que lhes aparecem. Quando Ihes aparece um problema, como eles já têm segurança e já resolveram problemas do género, já têm mais autonomia (Docente $P$ ).

Uma segunda posição reflecte as preocupações dos docentes com a incorporação do conhecimento obtido anteriormente e a relação entre a teoria e a prática. Neste contexto, os docentes defendem que a contextualização dos problemas que sistematicamente são apresentados aos alunos, permitem associar o conhecimento anteriormente obtido. Tal facto pode ser ilustrado com o exemplo a seguir do discurso na primeira pessoa:

A partir do momento em que há uma disciplina que lhes faz a interligação dos conhecimentos, em que eles conseguem visualizar a importância dos conhecimentos adquiridos em termos teóricos. E se (...) a Simulação Empresarial consegue-Ihes fazer ver que o objectivo em termos práticos é aquele, não tenho dúvidas nenhumas que os alunos no fim dizem "Olha, aquela cadeira que me custou tanto a fazer e que à partida não tinha interesse nenhum, tem agora aplicação aqui" (Docente S).

Apresenta-se, a seguir, um exemplo ilustrativo da identificação pelos actores, da força da metodologia da Simulação Empresarial na criação de pontes entre a comunidade empresarial e o mundo da educação:

Portanto saiu-se do ensino tradicional, e isso dava muito poucas capacidades aos alunos de aplicarem os conhecimentos teóricos e muito menos ou nada Ihes dava uma visão do que era a realidade. Neste aspecto foi um salto muito grande porque se passou de uma situação em que os conhecimentos que eram ministrados não tinham grande aderência à realidade profissional que os alunos iam encontrar, (...) para uma outra situação onde se procurou uma aplicação de elevado potencial (Docente K).

A terceira posição reflecte sobre a forma como os docentes significam o papel da metodologia na capacidade de motivar os alunos. A maioria dos docentes considera que a utilização do ambiente tipo PBL adoptado na 
disciplina é responsável pela motivação dos estudantes. A posição assumida por um dos docentes ilustra bem esta problemática:

Então se os professores os motivarem! Se os professores trouxerem situações da vida prática deles. Eu trabalho numa empresa de construção e tinha conhecimentos práticos. E colocava esta situação assim "Perante isto o que é que vocês faziam?" (Docente S).

Mas o ambiente proporcionado por metodologias PBL pode também ser muito perturbador para os alunos. Esta ideia é expressa pelos docentes quando acentuam que o carácter inovador da metodologia da Simulação Empresarial é passível de contribuir para uma motivação, com um efeito gradativo, à medida que os alunos ficam mais à vontade com a metodologia. Tal significa que o discurso dos actores indicia a presença de elementos motivadores na metodologia, elementos estes que parecem emergir de uma forma crescente. Este crescendo pode ser ilustrado com a seguinte afirmação:

No início é ao contrário. Porque no início há algum desconhecimento, algum receio de começar a trabalhar. E agora, a partir daqui, já não precisam de ter mais qualquer preocupação em termos de Simulação Empresarial porque ela agora já se desenvolve sozinha (Docente B).

Um dos entrevistados sublinhou a relação entre o desenvolvimento da auto-estima dos estudantes e a metodologia PBL:

Normalmente, os alunos chegam à Simulação Empresarial e não sabem muito bem o que vão fazer. Vêm mais ou menos motivados. Como vão entrar no desconhecido, ainda têm algumas reticências, alguma insegurança. $E$ depois, consoante vão cumprindo terminadas etapas, vão-se sentindo mais motivados e até orgulhosos (Docente E).

Neste ponto da apresentação dos resultados tentamos dar conta de um conjunto de percepções e tomadas de posição assumidas pelos actores entrevistados que conceptualizam a ideia de que a motivação pode ser atingida quer por razões intrínsecas, quer por razões extrínsecas. De entre as primeiras, os docentes salientam o resultado concertado entre um conjunto de especificidades inovadoras e os objectivos de aprendizagem. Relativamente às segundas, os académicos destacam a diversidade de problemas propostos e as características pragmáticas da disciplina. Um dos entrevistados sublinha:

O grande problema é, fundamentalmente, o da motivação dos alunos. (...) É a forma como a Simulação Empresarial é apresentada. (...) A partir do momento em que os alunos interiorizam que vamos estar a fazer uma simulação que é 
uma simulação da vida real, logicamente que a receptividade dos alunos é completamente diferente. Enquanto antigamente (...) eles no fim aprenderam os conhecimentos e pura e simplesmente desligam. (Docente S).

A quarta e última posição relaciona-se com a avaliação e o desempenho dos estudantes. Em contraponto com o modelo tradicional de avaliação enquanto modelo penalizador, vários entrevistados referem-se ao modelo de avaliação proposto pela metodologia PBL como um modelo capaz de fazer sobressair o bom desempenho dos estudantes. Nesta perspectiva, a metodologia parece assumir-se como uma mais-valia:

Nesta disciplina nunca chumbou ninguém. O que nós fazemos é o seguinte: damos sempre uma segunda hipótese de reformular o trabalho feito. Aqui cometem um erro e aprendem que não é assim que se faz e aprendem a fazer bem. A Simulação Empresarial tem uma série de elementos que funcionam como filtros aos erros que os alunos fazem (Docente B).

Da análise do discurso dos docentes sobre a problemática da avaliação, é ainda possível inferir que o sistema de avaliação proposto no contexto da simulação se revela bastante inclusivo, dado que lida com a capacidade de julgar e apreciar um profissional em acção. As palavras de dois dos entrevistados ilustram bem esta problemática:

O aspecto da avaliação é um dos pontos difíceis. Aliás, esse é exactamente o problema da avaliação das pessoas em situações profissionais (Docente K).

A componente da avaliação é para nós, docentes, um grande desafio porque é uma avaliação totalmente diferente das outras disciplinas (Docente F).

Um outro aspecto interessante emerge da análise do discurso dos actores. $E$ isto porque, para um número considerável de docentes, o modelo avaliativo proposto parece ter a capacidade de relacionar uma diversidade de elementos que, conjuntamente, contribuem para uma apreciação mais justa do trabalho desenvolvido pelos estudantes. O comentário seguinte realça esta percepção:

Portanto o problema foi arranjar métodos para valorizar também, além do produto final, o esforço das pessoas. A própria capacidade de trabalho das pessoas, aquilo que elas tentavam fazer com mais ou menos sucesso. Portanto, não era só medir o sucesso final, mas medir o esforço que as pessoas faziam para chegar a esse sucesso (Docente K). 
Em síntese, apesar da literatura científica apresentar a metodologia PBL como imbuída de elementos motivadores, o estudo empírico conduzido junto dos docentes, aponta algumas variáveis que importa reter na análise deste processo: as características motivacionais resultantes da utilização de metodologias PBL não são lineares nem imediatas.

\section{Discussão}

Na procura de incentivos para um melhor desempenho profissional, as IES de carácter profissionalizante têm-se empenhado em modificar os ambientes de aprendizagem que utilizam. Retomando as questões que formulámos para orientar o percurso da investigação, pretendemos compreender qual o poder dos ambientes de aprendizagem, nomeadamente os inspirados em metodologias $\mathrm{PBL}$, nas motivações dos estudantes e perceber até que ponto a motivação influencia os seus desempenhos.

$\mathrm{Na}$ busca de indicações de resposta a estas questões, orientados pela análise dos dados recolhidos junto dos alunos, diplomados e docentes e pela conceptualização do nosso objecto de estudo, procuramos, agora, proceder à discussão da informação obtida. A discussão encontra-se organizada em torno dos principais temas propostos pelas questões de investigação atrás apontadas.

\section{Desempenhos}

A maioria dos respondentes envolvidos no estudo refere-se à utilização da metodologia PBL como uma experiência que acresce valor às actividades pré-profissionais dos alunos. De facto, enquanto os docentes referem a possibilidade de partilharem a sua experiência profissional enquanto peritos na área, os alunos mencionam o reconhecimento da importância dos conhecimentos obtidos em unidades curriculares anteriores e os graduados citam o contributo que a metodologia dá à relação entre a teoria da sala de aula e a prática experienciada pela simulação.

Se, por um lado, os estudantes parecem sentir uma melhoria das suas competências como o resultado da sua experiência pré-profissional, por outro lado, os docentes parecem interiorizar o processo de simulação como uma experiência bastante próxima da vida profissional real com que os futuros 
graduados se depararão. Particularmente interessante é o facto desta mesma perspectiva ser partilhada pelos graduados quando já inseridos na vida profissional. Tendo estes pressupostos por referência, parece pois ser possível afirmar que, globalmente, estudantes e graduados valorizam a metodologia PBL, nomeadamente em termos de aprendizagem ao longo da vida.

A temática do desempenho foi, neste estudo, entendida quer em termos do que foi apreendido durante o processo PBL, quer em termos de resultados obtidos pelos alunos. Inversamente, parece-nos que há uma outra perspectiva: a do problema da real dinâmica do mundo empresarial. Por outras palavras, mesmo se é possível reconhecer às metodologias PBL um valor acrescentado na construção de pontes entre a teoria e a prática, visando uma maior transição entre a vida académica e a vida profissional, interrogamo-nos sobre qual o impacto no desempenho dos graduados, quando já inseridos no mercado de trabalho, da falta de todo um conjunto de relações pessoais, sociais e de troca de experiências entre os diversos elementos que se movem na arena empresarial. E aqui, podemos intensificar o debate introduzindo na discussão a perspectiva dos empregadores. Mas, tal como referimos inicialmente, a nossa intenção é a de levantar algumas questões que, também, possam apontar ideias e sugestões para trabalhos futuros.

Conforme já sabemos da literatura, ter feedback do trabalho realizado é um aspecto assaz importante no processo de ensino-aprendizagem (Ljungman \& Silén, 2008). Por outro lado, e como todos os inquiridos salientaram, o sistema avaliativo associado a metodologias PBL apresenta-se como um sistema complexo e delicado, inerente à situação de funcionar num ambiente aberto que envolve vários domínios, incluindo o social e o pessoal.

Tão longe quanto o conceito de avaliação formativa possa ir e na perspectiva da presente investigação, os respondentes ajuízam sentimentos bastante positivos decorrentes da forma de organização curricular das metodologias PBL, especialmente potenciadoras de atitudes de reflexão e de retorno de desempenho. Em particular, esta última faculdade assume um papel fulcral no bom desempenho do aluno. Tal centralidade decorre, não só da possibilidade que é colocada à disposição do aluno de alterar ou corrigir os trabalhos que vai realizando, como também da possibilidade de suscitar uma 
participação mais pró-activa e motivadora. Como consequência da melhoria efectiva do trabalho a realizar, os mecanismos de feedback assumem particular importância no entusiasmo e estímulo do estudante. Ou seja, é possível acrescentar à literatura a possibilidade da reformulação de trabalhos funcionar como filtro que permita aprender com o erro cometido. Nesta perspectiva, errar não se revela problemático, desde que não se persista no erro. Esta reabilitação do insucesso manifesta-se pois, de forma muito positiva, no desempenho dos alunos.

Permitimo-nos chamar aqui a atenção para o facto de os inquéritos e entrevistas realizadas se focarem (essencialmente) nos processos de retorno da parte dos docentes. Neste ponto parece-nos importante adicionar uma outra perspectiva: a do retorno dos trabalhos dos alunos pelos seus pares. $\mathrm{Na}$ nossa óptica, o simples facto do nosso estudo de caso decorrer em grupos de dois alunos apresenta-se como um elemento de definitiva importância na compreensão e valorização dos resultados finais apresentados por cada conjunto de trabalho.

\section{Motivações}

Os resultados encontrados no desenvolvimento empírico da presente investigação remetem-nos para a existência de alguns elementos recorrentes capazes de estimularem as motivações dos estudantes.

Apesar da maioria dos inquiridos referir o papel fulcral da metodologia na condução e produção do próprio conhecimento, nem todos lhe reconhecem a capacidade de cultivar competências como a autonomia ou a iniciativa. Recorde-se que todos os actores envolvidos neste estudo se encontraram sempre envolvidos em modelos tradicionais de ensino, sendo o estudo de caso que reportamos o primeiro contacto daqueles com uma metodologia tipo PBL.

Em traços gerais, o ambiente de simulação proposto pelas metodologias PBL, ao envolver uma perspectiva multidisciplinar de diferentes áreas de trabalho, parece ter a capacidade de se constituir como um agente catalisador de motivação. Se a estas características aliarmos, ainda, o potencial estímulo ao desenvolvimento de competências como autonomia, responsabilidade, auto-estima e auto-confiança, é possível sintetizar um conjunto de razões intrínsecas e extrínsecas geradoras de motivação nos 
alunos. Se, entre as primeiras, os inquiridos destacam a auto-motivação inerente à natureza inovadora de uma metodologia não tradicional, entre as segundas, o pragmatismo e as características quase reais validam as opiniões dos respondentes. Ou, como defendido por Araz \& Sungur (2007), entre as diversas variáveis responsáveis pela motivação dos estudantes, utilidade equivale a motivação extrínseca.

De acordo com os resultados empíricos, foi evidente um aumento das motivações dos alunos à medida que estes se encontravam mais à vontade com a metodologia PBL. Neste contexto, perspectivamos a possibilidade dos estudantes desenvolverem sentimentos motivacionais positivos mesmo que, inicialmente, tais sentimentos não existissem. No entanto, queremos crer que o simples facto de enfrentar uma situação desconhecida, em geral, não parece ser, per si, um factor gerador de motivação. Deste ponto de vista, parece-nos ser importante salvaguardar a hipótese de o mesmo pragmatismo que parece justificar razões externas se impor mais como um imperativo de resposta a necessidades concretas de resolução de situações, do que como motivação de novas formas de aprendizagem.

Para além deste conjunto de fenómenos, há também diferenças ao nível da forma como os mecanismos de retorno proporcionados pelo sistema avaliativo associado à metodologia se repercutem na motivação dos alunos. Ou seja, de entre os mecanismos que tornam os estudantes determinados na procura de melhor exercerem a sua futura profissão, ressalta a reorientação que os docentes proporcionam do trabalho realizado.

Nesta dinâmica complexa, importa não perder de vista a relação, necessariamente dinâmica e interactiva, entre elementos motivacionais e desempenho do aluno.

\section{Síntese e comparação}

Apesar de já realizadas a apresentação e discussão dos resultados explicitados, parece-nos útil para uma melhor compreensão dos mesmos, sintetizar, de modo comparativo e global, as três perspectivas a que nos referimos na presente investigação: a dos alunos, a dos diplomados e a dos docentes.

A temática do desempenho foi, ao longo deste estudo, entendida quer em termos de resultados obtidos pelos alunos, quer em termos do que foi apreendido durante o processo PBL. 
Todos os parceiros envolvidos na análise mantêm um clima de convergência no que respeita à descrição da produção do conhecimento como um dos aspectos mais importantes da metodologia PBL. Igualmente consensual é o entendimento dos alunos, graduados e docentes de que a contextualização dos problemas que sistematicamente são apresentados estimula a conexão e a integração entre a teoria escolar e a prática profissional. Numa perspectiva mais vasta, os dois aspectos acima referidos por todos os intervenientes no estudo parecem valorizar a metodologia PBL como instrumento impulsionador de mecanismos de aprendizagem ao longo da vida.

Menos consensual é a posição relativa à autonomia e iniciativa: enquanto, para alunos e docentes, a metodologia PBL parece proporcionar os instrumentos indispensáveis para aprendizagens mais independentes e empreendedoras, para os graduados, estes são aspectos que menos se evidenciam por força da metodologia.

Numa outra óptica, a percepção que os estudantes têm sobre o que os motiva e as percepções que os docentes têm sobre o que desperta o interesse e mobiliza a actividade dos alunos parecem-nos carecer de alguns ajustes. Referimo-nos, nomeadamente, ao processo de avaliação com retorno do trabalho realizado. Se as respostas dos alunos evidenciam que a avaliação nem sempre permite identificar claramente os objectivos a atingir e nem sempre fornece mecanismos de feedback, as entrevistas aos docentes referem-se ao modelo de avaliação proposto pela metodologia PBL como um modelo capaz de fazer sobressair o bom desempenho dos estudantes, exactamente por também permitir um ajuste destes aos objectivos que deles se esperam ao longo do processo.

Baseados nestas reflexões, importa-nos pois trazer à superfície a questão da motivação e consequente desempenho dos estudantes, perspectivada em duas vias: uma via gradativa que parece colocar os alunos mais à vontade com a metodologia à medida que a vão experienciando; e uma via que integra aspectos intrínsecos com aspectos extrínsecos inerentes à novidade e ao pragmatismo de uma metodologia que se apresenta, quer para alunos quer para docentes, com características nunca antes vividas em contexto escolar. 


\section{Conclusões}

De acordo com o quadro teórico da revisão da literatura, vários são os autores (e.g. Dahlgren \& Oberg, 2001) que enfatizam o facto das metodologias PBL reportarem grande motivação e um melhor desempenho entre os estudantes, quando comparadas com metodologias tradicionais de ensino. Este trabalho assumiu deliberadamente uma perspectiva multiescalas na análise do impacto das metodologias PBL nas motivações e consequentes desempenhos dos estudantes. Por isso, o estudo empírico que desenvolvemos foi concebido no sentido de tornar possível não só o seu confronto com as abordagens teóricas que seleccionámos, como, sobretudo, mostrar as discrepâncias entre a teoria e algumas situações práticas passíveis de uma análise mais fina. Assim, centramo-nos nas principais conclusões extraídas da análise dos resultados recolhidos, com o objectivo de estimular o debate teórico, apresentando, ainda, algumas pistas futuras de investigação.

O trabalho desenvolvido permite extrair um conjunto de dois tipos de razões que parecem justificar a presença e o reforço da motivação dos estudantes: razões intrínsecas (relacionadas com os aspectos inovadores da metodologia) e razões extrínsecas (arroladas às características pragmáticas e reais do processo PBL em ambientes simulados). Não obstante, questionamo-nos se aqueles mesmos aspectos não são responsáveis por algumas apreensões, referindo que o que pode ser motivador para alguns pode funcionar em sentido inverso com outros.

Um aspecto inovador, porventura menos evidenciado pela literatura, refere-se aos mecanismos de feedback (sobretudo dos docentes em relação aos alunos mas, também, dos alunos e seus pares). Nesta metodologia, errar pode não se revelar problemático uma vez que parece ser possível reabilitar o insucesso através de mecanismos de retorno do trabalho efectuado que, ao funcionarem como filtros, permitem ao aluno não só não persistir no erro mas, sobretudo, aprender com o erro cometido. Se bem que os resultados tenham de ser analisados com prudência, permitimo-nos formular a hipótese de que a reabilitação do insucesso académico dos estudantes através de mecanismos de feedback parece ser um factor formativo de atitudes de reflexão capaz de contribuir para um melhor desempenho e uma aprendizagem proactiva dos alunos. 
Por fim, a ideia unificadora subjacente a este raciocínio é a de que o desenvolvimento de sentimentos de motivação assume um papel pivô no desempenho dos alunos e dos futuros graduados. Ou, dito de outro modo, a motivação parece fazer a diferença nalgumas métricas relacionadas, quer com o que foi aprendido e interiorizado, quer com os resultados obtidos.

Num tempo em que se espera que as IES, nomeadamente as de carácter profissionalizante, contribuam, de forma decisiva, para o desenvolvimento de um vasto leque de competências (profissionais, sociais e pessoais) as metodologias PBL apresentam-se, cada vez mais, como um modelo alternativo. Admitindo que são as nossas referências que limitam a nossa qualidade e que o conhecimento deve ser centrífugo porque aberto ao mundo, parece-nos interessante repetir a aplicação do modelo com outras IES que contemplem, no seu currículo, disciplinas desenvolvidas em modelos PBL. A um nível mais particular, igualmente vantajosa se nos afigura a hipótese de introduzirmos na análise a perspectiva dos empregadores, porventura através da criação de um modelo sistemático de avaliação das necessidades destas entidades. No entanto, tal como salientado, importa analisar com cuidado o aspecto do equilíbrio entre a conceitualização teórica e a aplicação prática da mesma.

\section{Referências}

Albanese, M., \& Mitchell, S. (1993). Problem-based learning: A review of literature on its outcomes and implementation issues. Journal of the Association of American Medical Colleges, 68 (1), 52-81.

Araz, G., \& Semra, S. (2007). The interplay between cognitive and motivational variables in a problem-based learning environment. Learning and Individual Differences, 17(4), 291-297.

Arroteia, J. (2002). O Ensino Superior Politécnico em Portugal. Aveiro: Universidade de Aveiro.

Barrows, H. (1999). A taxonomy of problem-based learning methods. In J. Rankin (Org.), Handbook on problem-based learning (pp. 27-29). New York: Forbes Custom Publishing.

Bayne, S. (2007). Higher Education as a visual practice: seeing through the virtual learning environment. Teaching in Higher Education, 13 (4), 395-410.

Dahlgren, M., \& Öberg, G. (2001). Questioning to learn and learning to question: structure and function of problem-based learning scenarios in environmental science education. Higher Education, 41 (3), 263-282. 
De Vries, M., Schmidt, H., \& Graaff, E. (1989). Dutch comparisons: Cognitive and motivational effects of problem-based learning on medical students. In $\mathrm{H}$. Schmidt, M. Lipkin, M. de Vries \& J. Greep (Org.), New directions for medical education: Problem-based learning and community oriented medical education (pp. 230-240). New York: Springer-Verlag.

Frank, M., \& Barzilai, A. (2004). Integrating alternative assessment in a project-based learning course for pre-service science and technology teachers. Assessment \& Evaluation in Higher Education, 29 (1), 41-61.

Kirschner, P., Van Vilsteren, P., Hummel, H., \& Wigman, M. (1997). The design of a study environment for acquiring academic and professional competence. Studies in Higher Education, 22 (2), 151-171.

Kolmos, A. (1996). Reflections on project work and problem-based learning. European Journal of Engineering Education, 21 (2), 141-148.

Ljungman, A., \& Silén, C. (2008). Examination involving students as peer examiners. Assessment \& Evaluation in Higher Education, 33 (3), 289-300.

Maclellan, E. (2008). The significance of motivation in student-centred learning: a reflective case study. Teaching in Higher Education, 13 (4), 411-421.

Major, C., \& Palmer, B. (2001). Assessing the effectiveness of problem-based learning in Higher Education: Lessons from the literature. Academic Exchange Quartely, Spring 2001. Disponível em http://www.rapidintellect.com/AEQweb/ mop4spr01.htm.

Miles, M., \& Huberman, M. (1994). Qualitative data analysis. Thousand Oaks: Sage Publications.

Musal, B., Taskiran, C., \& Kelson, A. (2003). Opinions of tutors and students about the effectiveness of PBL in Dokuz Eylul University School of Medicine. Medical Education Online, 8. Disponível em http://www.med-ed-online.org/pdf/ f0000073.pdf.

Neave, G., \& van Vught, F. (1994). Government and higher education in developing nations: a conceptual framework. In G. Neave \& F. van Vught (Org.), Government and Higher Education relationships across three continents (pp. 122). Oxford: Press Pergamon.

Ordem dos Técnicos Oficiais de Contas (2010). Lista de cursos reconhecidos com protocolo de dispensa de estágio. Disponível em http://www.otoc.pt/gc/?id=294.

Rawson, M. (2000). Learning to learn: more than a skill set. Studies in Higher Education, 25 (2), 225-238.

Silén, C., \& Juhlin, L. (2008). Self-directed learning - a learning issue for students and faculty. Teaching in Higher Education, 13 (4), 461-475.

Tillema, H., Kessels, J., \& Meijers, J. (2000). Competencies as building blocks for integrating assessement with instructional in vocational education: a case from The Netherlands. Assessement \& Evaluation in Higher Education, 25 (3), 265278.

Yin, R. (1994). Case study research. Design and methods. Thousand Oaks: Sage Publications. 


\title{
MOTIVATION AND PERFORMANCE IN A BUSINESS SIMULATION COURSE
}

\begin{abstract}
In order to enhance graduates' performance in the labour market a one semester Business Simulation course was designed and implemented. The course participants are students of the last semester in a PBL-type undergraduate Portuguese Accounting program. This work focuses on the power of learning environments, namely the ones inspired by PBL, to influence students' motivations; and asks to what extent motivation contributes to differences in performance. Interpreting the results of this case study, it can be seen that the use of real-world problems encompassing different subject areas in conjunction with augmented teaching methods motivates students in both an intrinsic and extrinsic way. Using feedback together with the opportunity to improve submitted work is shown to have a huge importance on the learners' enthusiasm and stimulation. The effect that increased motivation has on students' and graduates' learning and ultimately course grades is a central tenet in the teaching and evaluation model.
\end{abstract}

Keywords

Higher education; PBL; Performance; Motivation

\section{MOTIVATION ET PERFORMANCE DANS UN COURS DE SIMULATION D'ENTREPRISE}

\section{Résumé}

Pour améliorer l'accomplissement des gradués dans le marché de travail, on a développé un cours de Simulation d'Enterprise, basé sur une méthodologie du type PBL. Ce travail se centre dans l'analyse sur le pouvoir des environnements d'apprentissage basés dans les méthodologies PBL sur les motivations des étudiants, et l'influence de la motivation sur l'accomplissement de ceux-là. L'investigation nous montre que la présence de problèmes 
professionnels réels enveloppant de différents domaines de travail, et la nature innovatrice de la méthodologie et ses caractéristiques pragmatiques, forment des éléments motivateurs pour les étudiants. En même temps, les mécanismes de feedback du travail réalisé et la possibilité de reformulation des erreurs commises assument une particulière importance pour l'enthousiasme et la stimulation de l'étudiant. L'effet que la croissante motivation a sur les apprentissages et sur les résultats dés étudiants c'est un paradigme central du modèle.

Mots-clé

Enseignement supérieur; PBL; Motivation; Performance

Recebido em Dezembro/2009 Aceite para publicação em Outubro/2010 
174 Margarida M. Pinheiro, Cláudia S. Sarrico \& Rui A. Santiago

\section{Anexo 1}

Universidade de Aveiro

Instituto Superior de Contabilidade e Administração

QUESTIONÁRIO AOS ALUNOS

do Projecto Profissional

O papel da simulaçăo nas aprendizagens no ensino superior.

Margarida Pinheiro

Universidade de Aveiro

Maio de 2004

||||||||||||||||||||||||| 
O presente inquérito, de natureza anónima, encontra-se integrado num trabalho de doutoramento proposto pela signatária, a decorrer na Universidade de Aveiro. relatório sobre os resultados da pesquisa nâo vai identificar as pessoas individuais, garantindo-se total confidencialidade.

A sua colaboraçăo é muito importante para nós. Desde já agradecemos a sua disponibilidade e atençăo.

1. Relativamente à metodologia seguida na disciplina de Projecto Profissional, com qual das afirmaçőes está mais 1. Relativamente a metodologia seguida na disciplina de Projecto Profissional, com qual das afirmaçóos)

1.1

O As aprendizagens na disciplina de Projecto Profissional permitem aumentar mais os meus conhecimentos teóricos do As aprendizagens na disciplina de Projecto
que as minhas competências técnicas.

O As aprendizagens na disciplina de Projecto Profissional permitem aumentar mais as minhas competências técnicas do que os meus conhecimentos teóricos. O As aprendizagens na disciplina de Projecto Profissional permitem aumentar tanto os meus conhecimentos teóricos

1.2

A metodologia seguida na disciplina de Projecto Profissional centra-se mais no ensino do que na aprendizagem.

O A metodologia seguida na disciplina de Projecto Profissional centra-se mais na aprendizagem do que no ensino.

O A metodologia seguida na disciplina de Projecto Profissional centra-se tanto no ensino como na aprendizagem.

1.3

- A metodologia seguida na disciplina de Projecto Profissional encoraja mais a aquisiçẳo de conhecimentos teóricos por si só, do que a aquisiçăo de conhecimentos té́ricos ligados à resoluçăo de problemas concretos.

- A metodologia seguida na disciplina de Projecto Profissional encoraja mais a aquisiçăo de conhecimentos teóricos ligados à resoluçắo de problemas concretos, do que a aquisiçăo de conhecimentos téćnicos por si só.

O A metodologia seguida na disciplina de Projecto Profissional encoraja tanto a aquisiçăo de conhecimentos teáricos por

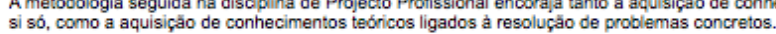

1.4

A metodologia seguida na disciplina de Projecto Profissional dificulta a aplicaçăo dos conhecimentos contabilistioos apreendidos anteriormente.

- A metodologia seguida na disciplina de Projecto Profissional facilita a aplicaçăo dos conhecimentos contabilisticos apreendidos anteriormente. O A metodologia seguida na disciplina de Projecto Profissional nâo dificulta nem facilita a aplicaçấo dos conhecimentos 
176 Margarida M. Pinheiro, Cláudia S. Sarrico \& Rui A. Santiago

A equipa docente envolvida na disciplina de Projecto Profissional indica mais uma visâo global orientadora do caminho a

A equipa docente envolvida na disciplina de Projecto Profissional intervem mais directamente na resoluçẳo de problemas dc que indica uma visaao global orientadora do caminho a seguir.

- A equipa docente envolvida na disciplina de Projecto Profissional indica tanto uma visão global orientadora do caminho a seguir como intervem directamente na resoluçâo de problemas.

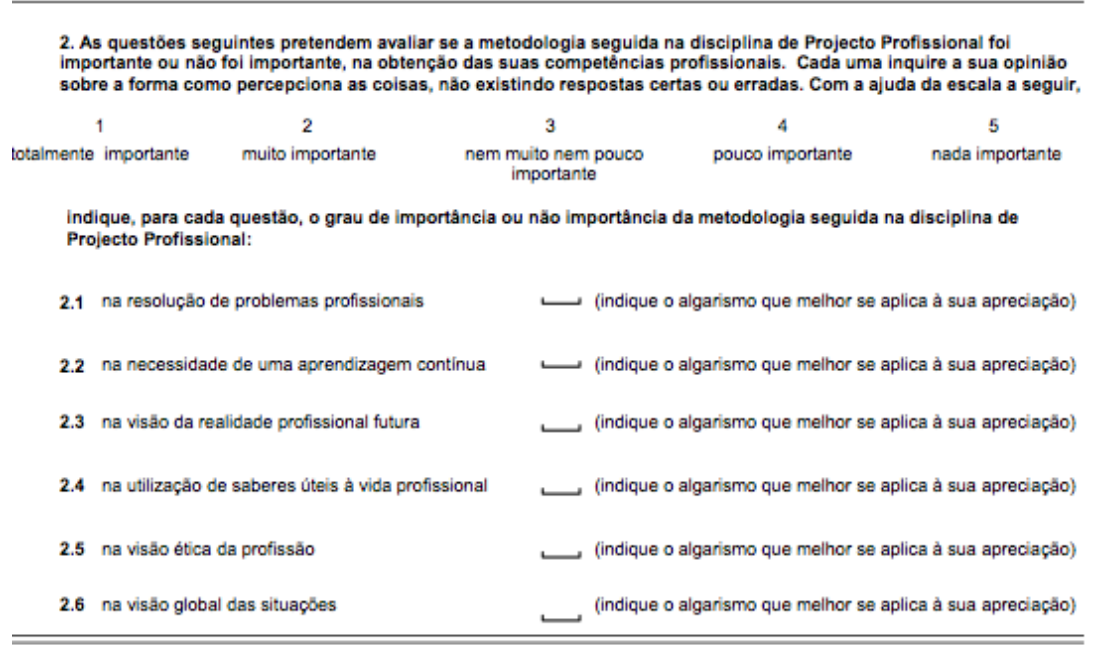

3. As questōes seguintes pretendem avaliar qual o papel da metodologia seguida na disciplina de Projecto Profissional, nas suas aprendizagens. Cada uma inquire a sua opiniào sobre a forma como percepciona as coisas, năo existindo respostas certas ou erradas. Com a ajuda da escala a seguir

$\begin{array}{ccccc}1 & 2 & 3 & 4 & 5 \\ \text { concordo } & \text { concordo parcialmente } & \text { nem concordo nem discordo } & \text { discordo parcialmente } & \text { discordo }\end{array}$

indique o seu grau de concordância ou năo concordância com cada uma das afirmaçöes seguintes:

3.1 A disciplina de Projecto Profissional desenvolve-se (indique o algarismo que melhor se aplica à sua apreciaçăo)

3.2 A disciplina de Projecto Profissional tem a

ـ (indique o algarismo que melhor se aplica à sua apreciaçăo)

.3 A disciplina de Projecto Profissional tem uma visäo crientada para a resoluch a de problemas concretos.

3.4 A metodologia seguida na disciplina de Projecto complexidade das situaçóes em ambiente real.

(indique o algarismo que melhor se aplica à sua apreciaçăo) (indique o algarismo que melhor se aplica à sua apreciaçăo) 
3.5 A disciplina de Projecto Profissional assenta numa aprendizagem sem separaçấo entre a teoria e a sua aplicaçắo prática.

3.6 A disciplina de Projecto Profissional fornece conhecimentos que habilitam os alunos a resolver

3.7 A disciplina de Projecto Profissional encoraja uma aprendizagem auto-dirigida.

3.8 A recriaçăa de ambientes profissionais virtuais na disciplina de Projecto Proissiona oferece uma visăo próxima da realidade que simulam.

3.9 A recriaçấo de ambientes profissionais virtuais na disciplina de Projecto Profissional permite que os $ـ \quad$ (indique o algarismo que melhor se aplica à sua apreciaçăo) alunos adquiram um maior número de competências. (indique o algarismo que melhor se aplica à sua apreciação

3.10 A equipa docente envolvida na disciplina de Projecto Protissional torna claras as competéncias que se (indique o algarismo que melhor se aplica à sua apreciação)

11 A equipa docente envolvida na disciplina de Projecto Profipsionale ente fornece aos alunos.

3.12 A disciplina de Projecto Profissional integra saberes disciplinares obtidos em anos anteriores do curso.

(indique o algarismo que melhor se aplica à sua apreciação)

ــ (indique o algarismo que melhor se aplica à sua apreciaçăo)

(indique o algarismo que melhor se aplica à sua apreciaçăo) (indique o algarismo que melhor se aplica à sua apreciação) (indique o algarismo que melhor se aplica à sua apreciação)

Se respondeu "concordo" cu "concordo parcialmente", responda às questóes 3.12.1 e 3.12.2. Caso contrário, gasse à questâa 3.12.1 P metodologia seguida na disciplina de Projecto
Profissional utliza as técnicas necessárias para tomar operacionais esses saberes.

A metodologia seguida na disciplina de Projecto Profissional ut liza as práticas necessárias para tomar operacionais esses saberes.

\author{
ــ (indique o algarismo que melhor se aplica à sua apreciação) \\ (indique o algarismo que melhor se aplica à sua apreciaçăo)
}

4. As questőes seguintes pretendem saber que avaliaçăo faz das suas competências sociais, em funçăo da metodologia seguida na disciplina de Projecto Profissional. Cada uma inquire a sua opiniăo sobre a forma como percepciona as coisas, năo existindo respostas certas ou erradas. Com a ajuda da escala a seguir

$\begin{array}{ccccc}1 & 2 & 3 & 4 & 5 \\ \text { concordo } & \text { concordo parcialmente } & \text { nem concordo nem discordo } & \text { discordo parcialmente } & \text { discordo }\end{array}$

indique o seu grau de concordância ou năo concordância com cada uma das afirmaçốes seguintes:

(preencha o circulo que melhor exprime a sua opiniăo) $\begin{array}{llllll}\text { 4.1 A metodologia seguida na disciplina de Projecto } & 1 & 2 & 3 & 4 & 5 \\ \text { Profissional permite-me desenvolver competências } & 0 & 0 & 0 & 0 & 0\end{array}$ a nivel do trabalho em equipa.

4.2 A metodologia seguida na disciplina de Projecto Profissional permite-me desenvolver capacidades de liderança.

O

O

O

O 
178 Margarida M. Pinheiro, Cláudia S. Sarrico \& Rui A. Santiago

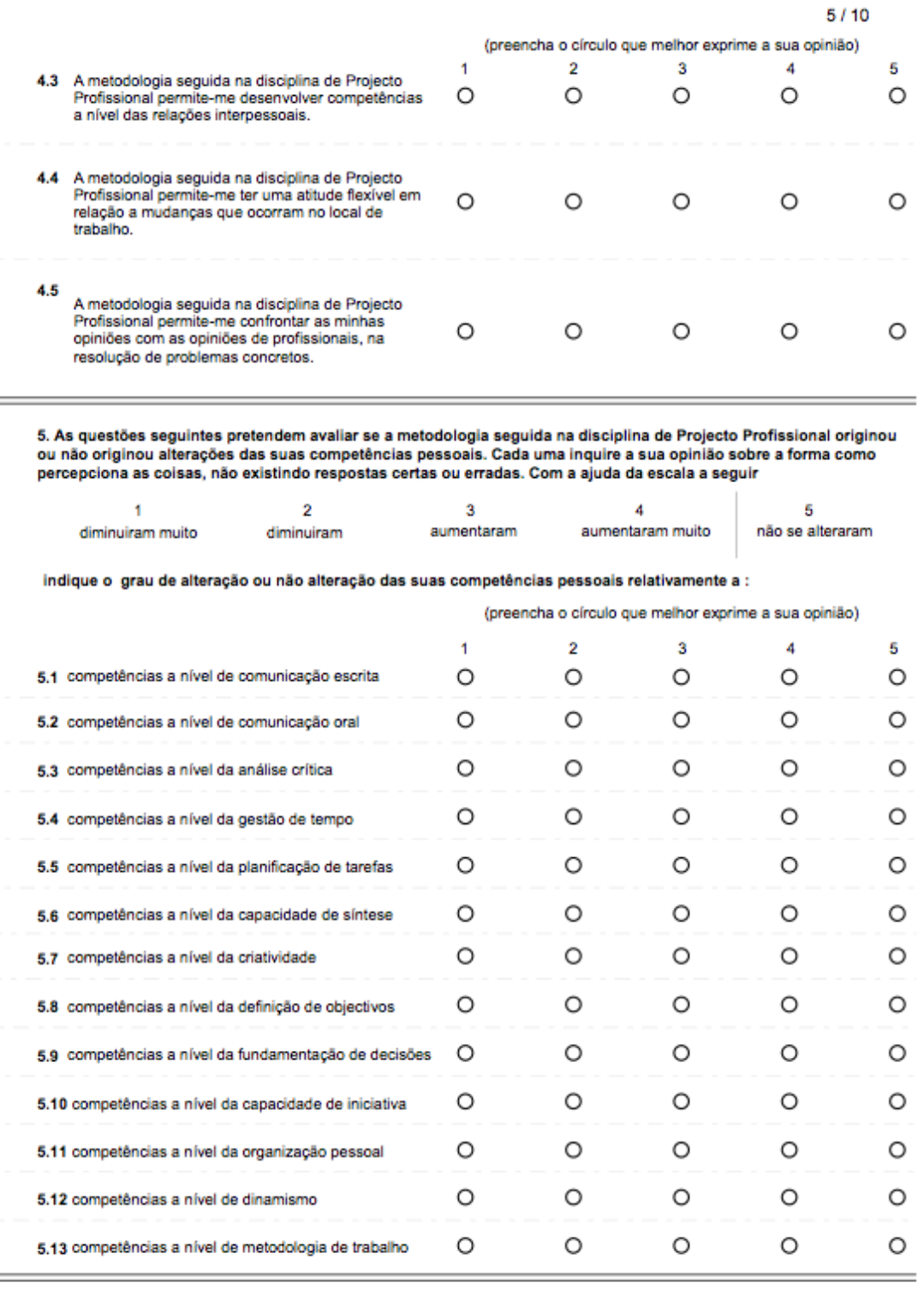


6. Na lista de domínios da tabela em baixo designados, indique:

a) o grau de importância ou năo importância que atribui a cada domínio na construçăo do perfil de um graduado. Utilize ${ }_{1}$

$$
2
$$
3 4
nada importante
pouco importante
nem muito nem pouco
muito importante

$$
5
$$

b) se a metodologia seguida na disciplina de Projecto Profissional foi determinante ou năo foi determinante na obtençăo desse domínio. Utilize a escala

\begin{tabular}{|c|c|c|}
\hline \multirow[t]{2}{*}{ Dominio } & $\begin{array}{l}\text { a) o grau de importâncla ou nảo importância } \\
\text { que atribui a cada dominio na construçăo do } \\
\text { perfil dum graduado }\end{array}$ & $\begin{array}{l}\text { b) se a metodologia seguida na } \\
\text { disciplina de Projecto Profissional foi } \\
\text { determinante ou năo fol determinante na } \\
\text { obtençăo desse domínio }\end{array}$ \\
\hline & \multicolumn{2}{|c|}{ (Escreva o algarismo que melhor se adequa à sua apreciaçâo) } \\
\hline $\begin{array}{l}\text { Valorizaçăo } \\
\text { do trabalho } \\
\text { do outro }\end{array}$ & $\smile$ & $\smile$ \\
\hline $\begin{array}{l}\text { Valorizaçăo } \\
\text { do trabalho } \\
\text { pessoal }\end{array}$ & 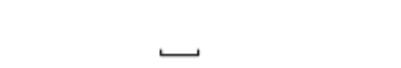 & 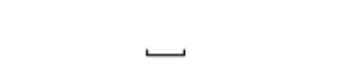 \\
\hline $\begin{array}{l}\text { Visâo global } \\
\text { das situaç̧es }\end{array}$ & ـ & ـ \\
\hline $\begin{array}{l}\text { Visấo ética } \\
\text { da profissấo }\end{array}$ & 巴 & 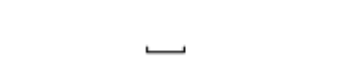 \\
\hline $\begin{array}{l}\text { Visão da realidade } \\
\text { profissional futura }\end{array}$ & ـ & ـ \\
\hline $\begin{array}{l}\text { Aprendizagem } \\
\text { continua }\end{array}$ & ـ & 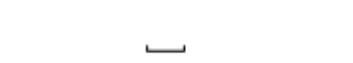 \\
\hline $\begin{array}{l}\text { Resoluçăo de } \\
\text { problemas } \\
\text { profissionais }\end{array}$ & $\smile$ & $\smile$ \\
\hline $\begin{array}{l}\text { Metodologia } \\
\text { de trabalho }\end{array}$ & ـ & ـ \\
\hline Dinamismo & ש & 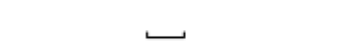 \\
\hline $\begin{array}{c}\text { Organizaçäo } \\
\text { pessoal }\end{array}$ & 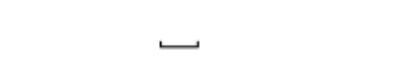 & ـ \\
\hline $\begin{array}{l}\text { Capacidade } \\
\text { de iniciativa }\end{array}$ & ـ & ـ \\
\hline
\end{tabular}

$\begin{array}{ccccc}1 & 2 & 3 & 4 & 5 \\ \text { nada determinante } & \text { pouco determinante } & \begin{array}{c}\text { nem muito nem pouco } \\ \text { determinante }\end{array} & \text { muito determinante } & \text { totalmente determinante }\end{array}$

||||||||||||||||||||||||||||||||| 
180 Margarida M. Pinheiro, Cláudia S. Sarrico \& Rui A. Santiago

Continuaçăo da questão número 6 .

\begin{tabular}{|c|c|c|}
\hline \multirow[t]{2}{*}{ Dominio } & $\begin{array}{l}\text { a) o grau de importância ou năo importância } \\
\text { que atribui a cada dominio na construçăo do } \\
\text { perfil dum graduado }\end{array}$ & $\begin{array}{l}\text { b) se a metodologia seguida na } \\
\text { disciplina de Projecto Profissional fol } \\
\text { determinante ou năo foi determinante na } \\
\text { obtençăo desse domínio }\end{array}$ \\
\hline & \multicolumn{2}{|c|}{ (Escreva o algarismo que melhor se adequa à sua apreciaçăo) } \\
\hline $\begin{array}{l}\text { Fundamentaçäo } \\
\text { de decisbes }\end{array}$ & ـ & ـ \\
\hline $\begin{array}{l}\text { Definiçâo de } \\
\text { objectivos }\end{array}$ & ـ & ـ \\
\hline Criatividade & ـ & ـ \\
\hline $\begin{array}{l}\text { Capacidade } \\
\text { de sintese }\end{array}$ & ـ & ـ \\
\hline $\begin{array}{l}\text { Planificaçăo de } \\
\text { tarefas }\end{array}$ & ـ & — \\
\hline $\begin{array}{l}\text { Gestāo do } \\
\text { tempo }\end{array}$ & 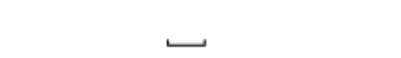 & ـ \\
\hline $\begin{array}{l}\text { Análise } \\
\text { critica }\end{array}$ & ـ & — \\
\hline $\begin{array}{l}\text { Comunicaçäo } \\
\text { oral }\end{array}$ & ـ & ـ \\
\hline $\begin{array}{c}\text { Comunicaçăo } \\
\text { escrita }\end{array}$ & ש & ـ \\
\hline $\begin{array}{l}\text { Confrontaçäo } \\
\text { de opinibes }\end{array}$ & ـ & ـ \\
\hline $\begin{array}{l}\text { Flexibilidade a } \\
\text { mudanças }\end{array}$ & ש & - \\
\hline $\begin{array}{c}\text { Relaçōes } \\
\text { interpessoais }\end{array}$ & ـ & ـ \\
\hline $\begin{array}{l}\text { Capacidade } \\
\text { de liderança }\end{array}$ & $\smile$ & — \\
\hline $\begin{array}{l}\text { Trabalho } \\
\text { em equipa }\end{array}$ & ـ & ـ \\
\hline
\end{tabular}


7. Relativamente à metodologia seguida na disciplina de Projecto Profissional, com qual das afirmaçōes está mais de acordo? (Seleccione apenas uma das questóes, preenchendo o circulo que melhor exprime a sua opiniäo).

7.1

A metodologia seguida na disciplina de Projecto Profissional nâo me incentiva a identificar as minhas necessidades de aprendizagem, nem me leva a assumir uma participaçăo activa nessas mesmas aprendizagens. A metodologia seguida na disciplina de Projecto Profissional năo me incentiva a identificar as minhas necessidades de
aprendizagem, mas leva-me a assumir uma participaçăo activa nessas mesmas aprendizagens.

- A metodologia seguida na disciplina de Projecto Profissional incentiva-me a identificar as minhas necessidades de aprendizagem, mas não me leva a assumir uma participaçấo activa nessas mesmas aprendizagens.

- A metodologia seguida na disciplina de Projecto Profissional incentiva-me a identificar as minhas necessidades de aprendizagem e leva-me a assumir uma participaçăo activa nessas mesmas aprendizagens.

7.2

A metodologia seguida na disciplina de Projecto Profissional permite-me reconhecer que as minhas opinióes nấo săo valarizadas nem pelos meus pares nem pela equipa docente.

A metodologia seguida na disciplina de Projecto Profissional permite-me reconhecer que as minhas opiniốes nâo sấo valorizadas pelos meus pares mas săo valorizadas pela equipa docente.

A metodologia seguida na disciplina de Projecto Profissional permite-me reconhecer que as minhas opinióes são valorizadas pelos meus pares mas nāo săo valonizadas pela equipa docente.

- A metodologia seguida na disciplina de Projecto Profissional permite-me reconhecer que as minhas opinióes săo valorizadas pelos meus pares e pela equipa docente.

8. As questő̀es seguintes pretendem saber que avaliaçăo faz das suas motivaçồes e dos seus desempenhos, em
funçăo da metodologia seguida na disciplina de Projecto Profissional. Cada uma inquire a sua opiniăo sobre a form como percepciona as coisas, năo existindo respostas certas ou erradas. Indique o seu grau de concordância ou năo concordância com cada uma das afirmaçöes que se seguem, utilizando a escala de respostas

$5=$ de acordo

$4=$ parcialmente de acordo

$3=$ nem de acordo nem em desacordo

$2=$ parcialmente em desacordo

$1=\mathrm{em}$ desacordo

8.1 A metodologia seguida na disciplina de Projecto Profissiona incentiva-ma

(preencha o circulo que melhor exprime a sua opiniäo)

$\begin{array}{lllll}1 & 2 & 3 & 4 & 5 \\ 0 & 0 & 0 & 0 & 0\end{array}$

8.2 A metodologia seguida na disciplina de Projecto Profissiona motiva-me para uma aprendizagem permanente.

8.3 A metodologia seguida na disciplina de Projecto Profissional permite-me reconhecer que a aprendizagem näo passa apen processo de os adquirir.

8.4 A metodologia seguida na disciplina de Projecto Profissiona incentiva a minha capacidade de iniciativa. 
182 Margarida M. Pinheiro, Cláudia S. Sarrico \& Rui A. Santiago

$9 / 10$

9. Relativamente à avaliaçăo da disciplina de Projecto Profissional e para cada uma das questöes indicadas, assinale apenas uma das opçōes.

9.1 O processe de avaliaga a disciplina de Projecto Profssional permite-me O Sim identificar quais os resultados das aprendizagens que se pretendem?

9.2 Ao longo do tempo de funcionamento da disciplina de Projecto Profissional, O Sim equipa docente? O Não (Se respondeu negativamente

9.2.1 Essa oportunidade permitiu-me reformular os resultados do meu trabalho,

O sim

O Năo

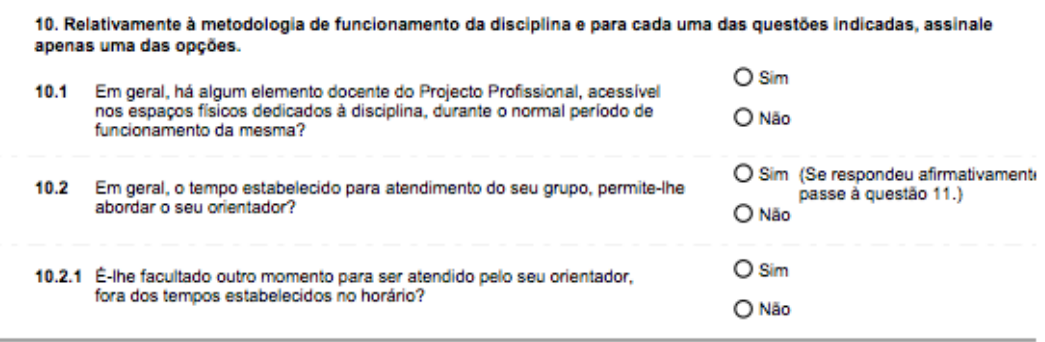

11. Qual a sua situaçăo académica actual? (Assinale apenas uma resposta)

O Näo possuo qualquer grau académico

Possuo um bacharelato em contabilidade

O Possuo outro bacharelato

O Possuo uma licenciatura em contabilidade

O Possuo outra licenciatura

12. Experiência de trabalho na área da contabilidade. (Assinale apenas uma resposta)

O Nunca trabalhei na área da contabilidade

O Actualmente trabalho na área da contabilidade

O Actualmente nâo trabalho na área da contabilidade, mas já trabalhei

13. Regime de matricula no curso. (Assinale apenas uma resposta)

O Regime diurno

Regime nocturno 


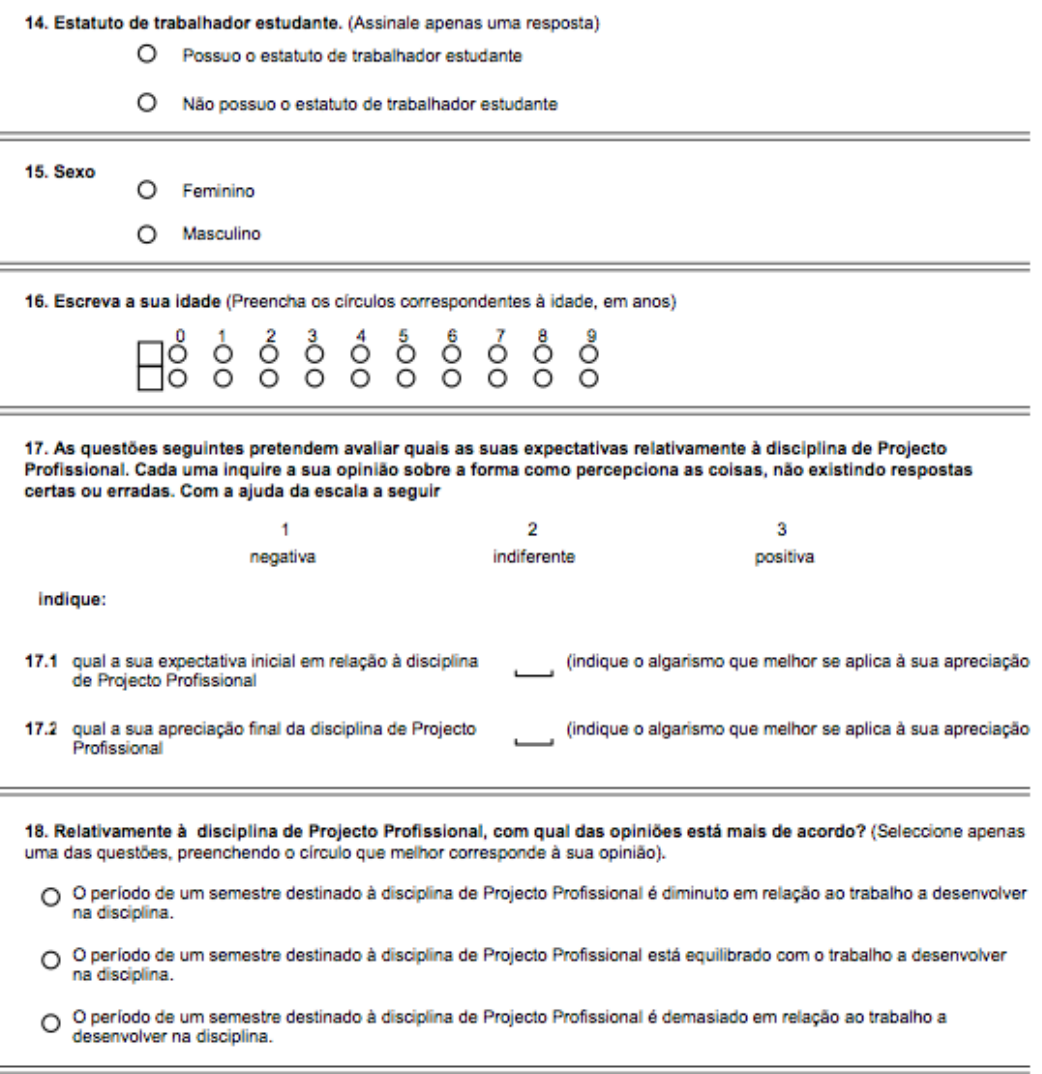

Obrigada pela sua participação

||||||||||||||||||||||||||||||| || 
184 Margarida M. Pinheiro, Cláudia S. Sarrico \& Rui A. Santiago

\section{Anexo 2}

Universidade de Aveiro

Instituto Superior de Contabilidade e Administraçäo

QUESTIONÁRIO AOS DIPLOMADOS

que frequentaram a disciplina de

Proiecto Profissional no ISCA-UA

O papel da simulaçăo nas aprendizagens no ensino superior.

Margarida Pinheiro

Universidade de Aveiro

Fevereiro de 2005 
O presente inquérito, de natureza anónima, encontra-se integrado num trabalho de doutoramento proposto pela signatária e a decorrer na Universidade de Aveiro. O objectivo geral deste nosso estudo é o de analisar qual o impacto da utilizaçăo da disciplina de Projecto Profissional nas aprendizagens em contabilidade no ISCA-UA.

Para além da justificaçăo da pertinência do tema a que nos propomos baseada na literatura científica e na prática pessoal desta escola, acresce a necessidade de confirmar cientificamente a validade da experiência empírica do Projecto Profissional, cujos resultados poderăo contribuir para a construçăo do conhecimento sobre as metodologias de ensino ao nível da educação superior, no sentido de obter uma melhor compreensão da organizaçăo e da gestâo curricular no ensino-aprendizagem.

Os enunciados contidos neste inquérito, destinam-se a conhecer factos, medir atitudes, opiniỏes e satisfaçōes. Cada uma das questōes a seguir apresentadas, inquire a sua opinião sobre a forma como percepciona o que o rodeia, năo existindo respostas certas ou erradas. Desde já agradecemos a sua disponibilidade e atençăo. A sua colaboração é importante para nós. OBRIGADA.

\section{Instruçōes para preenchimento do questionário}

As respostas serảo sujeitas a tratamento por leitura óptica, pelo que deve ter em atençăo o seguinte:

- O inquérito deve ser preenchido utlizando esferográfica azul ou preta:

- Nos casos em que a resposta é obtida mediante o preenchimento de um circulo, o espaço do circulo deve ser assinalado

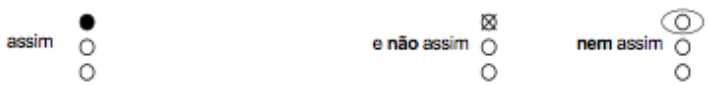

- Nos casos em que a resposta é obtida mediante uma informaçăo numérica através de um quadro, deve utlizar-se o procedimento referido no ponto anterior, tendo o cuidado de preencher um circulo por linha, tal como indica o exemplo $\begin{array}{llllllllll}1 & 2 & 3 & 4 & 5 & 6 & 7 & 8 & 9 & 0\end{array}$

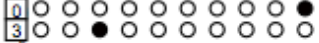

- Nos casos em que a resposta é obtida mediante uma informaçâa numérica de um único algarismo, deve o mesmo ser escrito de forma legivel, tal como indica o exemplo junto 
186 Margarida M. Pinheiro, Cláudia S. Sarrico \& Rui A. Santiago

1. Disciplina de Projecto Profissional. (Assinale apenas uma resposta)

O Frequentei a disciplina de Projecto Profissional.

O Nāo frequentei a disciplina de Projecto Profissional. (Termina aqui o seu questionário)

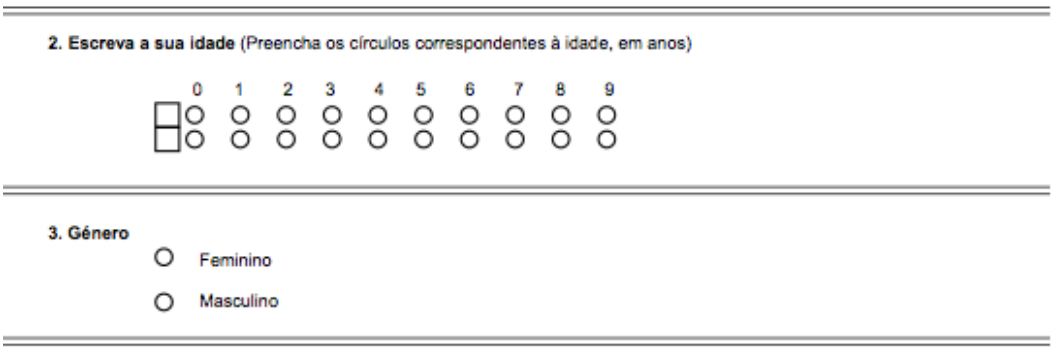

4. Indique o ano de conclusåo do seu bacharelato no ISCA-UA (Preencha os clirculos correspondentes)

$\begin{array}{llllllllll}0 & 1 & 2 & 3 & 4 & 5 & 6 & 7 & 8 & 9\end{array}$

$\begin{array}{rllllllllll}1 & 0 & 0 & 0 & 0 & 0 & 0 & 0 & 0 & 0 & 0\end{array}$

-10

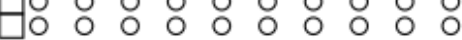

5. Regime de matrícula no curso à data da frequência da disciplina de Projecto Profissional. (Assinale apenas uma 5. Regime de

O Regime diurno

Regime nocturno

6. Estatuto à data da frequência da disciplina de Projecto Profissional. (Assinale apenas uma resposta)

Trabalhador estudante

Ordinário

O Outro estatuto

7. Experiência de trabalho na área da contabilidade. (Assinale apenas uma resposta)

O Nunca trabalhei na área da contabilidade. (Passe à questão 10)

O Actualmente trabalho na área da contabilidade.

O Actualmente nåo trabalho na área da contabilidade, mas já trabalhei. 


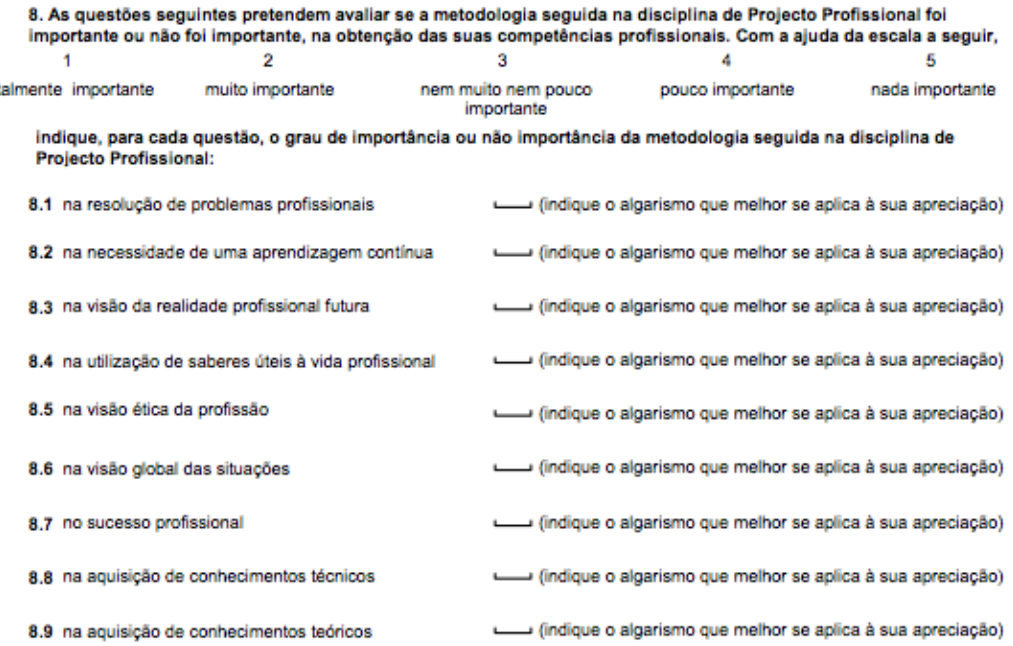

9. As questões seguintes pretendem avaliar qual o papel da metodologia seguida na disciplina de Projecto Profissional

$\begin{array}{ccccc}1 & 2 & 3 & 4 & 5 \\ \text { concordo } & \text { concordo parcialmente } & \text { nem concordo nem discordo } & \text { discordo parcialmente } & \text { discordo }\end{array}$

indique o seu grau de concordância ou nầo concordância com cada uma das afirmaçö́es seguintes:

9.1 A disciplina de Projecto Profissional desenvolve-se ـ (indique o algarismo que melhor se aplica à sua apreciaçăo) em que o aluno se integrará.

9.2 A disciplina de Projecto Profissional tem a ambiente real.

9.3 A disciplina de Projecto Profissional tem uma visăo $ـ$ (indique o algarismo que melhor se aplica à sua apreciaçăo)

9.4 A metodologia seguida na disciplina de Projecto Profissional permite o entendimento da
complexidade das situaços em ambiente real.

9.5 A disciplina de Projecto Profissional formece habilitam os alunos a resolver novas situaçōes.

9.6 A disciplina de Projecto Profissional encoraja uma aprendizagem auto-dirigida.

9.7 A recriaçäo de ambientes profissionais virtuais na disciplina de Projecto Profissional oferece uma visâo próxima da realidade que simulam. disciplina de Projeintes profssionais viruais na alunos adquiram um maior número de competêncigs.

9.9 A recriaçăo de ambientes profissionais virtuais na disciplina de Projecto Profissional permite dar contratarem diplomadas possuipregador de contratarem diplomadoss possuidores de
número de competéncias profissionais.

ـ (indique o algarismo que melhor se aplica à sua apreciaçăo)

ـ (indique o algarismo que melhor se aplica à sua apreciaçăo)

—. (indique o algarismo que melhor se aplica à sua apreciaçẩ)

ـ. (indique o algarismo que melhor se aplica à sua apreciaçăo)

ــ (indique o algarismo que melhor se aplica à sua apreciaçăo)

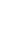
ــ (indique o algarismo que melhor se aplica à sua apreciaçấ) || |||||||||||||||||||||||| 
188 Margarida M. Pinheiro, Cláudia S. Sarrico \& Rui A. Santiago

10. As questōes seguintes pretendem saber que avaliaçâo faz das suas competências sociais, em funçâo da metodologia seguida na disciplina de Projecto Profissional. Com a ajuda da escala a seguir
1 2 2
concordo parcialmente nem concordo $n$ 4
concordo parcialmente 5

indique o seu grau de concordância ou năo concordância com cada uma das afirmaçōes seguintes:

\begin{tabular}{|c|c|c|c|c|c|c|}
\hline \multirow[b]{3}{*}{10.1} & \multirow[b]{3}{*}{$\begin{array}{l}\text { A metodologia seguida na disciplina de Projecto } \\
\text { Profissional permite-me desenvolver competências } \\
\text { a nivel do trabalho em equipa. }\end{array}$} & \multicolumn{5}{|c|}{ (preencha o circulo que melhor exprime a sua opinião) } \\
\hline & & 1 & 2 & 3 & 4 & 5 \\
\hline & & 0 & 0 & 0 & 0 & 0 \\
\hline 10.2 & $\begin{array}{l}\text { A metodologia seguida na disciplina de Projecto } \\
\text { Profissional permite-me desenvolver capacidades } \\
\text { de liderança. }\end{array}$ & O & 0 & 0 & 0 & 0 \\
\hline 10.3 & $\begin{array}{l}\text { A metodologia seguida na disciplina de Projecto } \\
\text { Profissional permite-me desenvolver competências } \\
\text { a nivel das relaçoes interpessoais. }\end{array}$ & 0 & 0 & 0 & 0 & 0 \\
\hline 10.4 & $\begin{array}{l}\text { A metodologia seguida na disciplina de Projecto } \\
\text { Profissional permite-me ter uma atitude flexivel em } \\
\text { relaçáo a mudanças que ocorram no local de } \\
\text { trabalho. }\end{array}$ & 0 & 0 & 0 & 0 & 0 \\
\hline 10.5 & $\begin{array}{l}\text { A metodologia seguida na disciplina de Projecto } \\
\text { Profissional permite-me confrontar as minhas } \\
\text { opiniōes com as opinióes de profissionais, na } \\
\text { resoluçäo de problemas concretos. }\end{array}$ & 0 & 0 & 0 & 0 & O \\
\hline
\end{tabular}

11. As questôes seguintes pretendem avaliar se a metodologia seguida na disciplina de Projecto Profissional originou ou nāo originou alteraçóes das suas competências pessoais. Com a ajuda da escala a seguir
diminuiram muito
2
diminuiram
$\stackrel{3}{\text { aumentaram }}$
$\stackrel{4}{4}$
5

indique o grau de alteraçăo ou năo alteraçăo das suas competéncias pessoais relativamente a :

\begin{tabular}{|c|c|c|c|c|c|c|}
\hline & & \multicolumn{5}{|c|}{ (preencha o circulo que melhor exprime a sua opiniäo) } \\
\hline & & 1 & 2 & 3 & 4 & 5 \\
\hline 11.1 & competências a nivel de comunicação escrita & O & 0 & O & $\mathrm{O}$ & $\mathrm{O}$ \\
\hline 11.2 & competências a nivel de comunicação oral & $\mathrm{O}$ & $\mathrm{O}$ & O & $\mathrm{O}$ & $\mathrm{O}$ \\
\hline 11.3 & competências a nivel da análise critica & O & 0 & O & $\mathrm{O}$ & O \\
\hline 11.4 & competências a nivel da gestâo de tempo & $\mathrm{O}$ & $\mathrm{O}$ & O & $\mathrm{O}$ & $\mathrm{O}$ \\
\hline 11.5 & competéncias a nivel da planificaçă̊ de tarefas & O & O & O & $\mathrm{O}$ & O \\
\hline 11.6 & competéncias a nivel da capacidade de síntese & $\mathrm{O}$ & O & O & $\mathrm{O}$ & $\mathrm{O}$ \\
\hline 11.7 & competências a nivel da criatividade & O & $\mathrm{O}$ & O & $\mathrm{O}$ & $\mathrm{O}$ \\
\hline 11.8 & competéncias a nivel da definiçăo de objectivos & $\mathrm{O}$ & $\mathrm{O}$ & $\mathrm{O}$ & $\mathrm{O}$ & $\mathrm{O}$ \\
\hline 11.9 & competéncias a nivel da fundamentaçăo de decisóes & $\mathrm{O}$ & $\mathrm{O}$ & O & $\mathrm{O}$ & O \\
\hline 11.10 & competências a nivel da capacidade de iniciativa & $\mathrm{O}$ & 0 & O & $\mathrm{O}$ & O \\
\hline 11.11 & competências a nivel da organizaçấo pessoal & $\mathrm{O}$ & O & O & $\mathrm{O}$ & $\mathrm{O}$ \\
\hline 11.12 & competências a nivel de dinamismo & O & $\mathrm{O}$ & O & $\mathrm{O}$ & $\mathrm{O}$ \\
\hline 11.13 & competências a nivel de metodologia de trabalho & $\mathrm{O}$ & $\mathrm{O}$ & $\mathrm{O}$ & $\mathrm{O}$ & $\mathrm{O}$ \\
\hline
\end{tabular}


12. Na lista de domínios da tabela em baixo designados, indique:

a) o grau de importáncia ou não importância que atribui a cada domínio na construçăo do perfil de um diplomado. $\begin{array}{lllll}\text { Utilize a escala } & 2 & 3 & 4 & 5\end{array}$ nada importante pouco importante nem muito nem pouco muito importante totalmente importante

b) se a metodologia seguida na disciplina de Projecto Profissional foi determinante ou năo fol determinante na obtençăo desse domínio. Utilize a escala nada determinante pouco determinante $\begin{gathered}\text { nem muito nem pouco muito determinante } \\ \text { determinante }\end{gathered}$ totalmente determinante

\begin{tabular}{|c|c|c|}
\hline \multirow[t]{2}{*}{ Dominio } & $\begin{array}{l}\text { a) o grau de importância ou năo importâncla } \\
\text { que atribui a cada domínio na construçăo do } \\
\text { perfill dum diplomado. }\end{array}$ & $\begin{array}{l}\text { b) se a metodologia seguida na } \\
\text { disciplina de Projecto Profissional fol } \\
\text { determinante ou năo foi determinante na } \\
\text { obtenção desse domínio. }\end{array}$ \\
\hline & \multicolumn{2}{|c|}{ (Escreva $\circ$ algarismo que melhor se adequa à sua apreciaçäo) } \\
\hline $\begin{array}{l}\text { Valorizaçăo } \\
\text { do trabalho } \\
\text { do outro }\end{array}$ & — & 巴 \\
\hline $\begin{array}{l}\text { Valorizaçấo } \\
\text { do trabalho } \\
\text { pessoal }\end{array}$ & $\smile$ & ـ \\
\hline $\begin{array}{l}\text { Visáo global } \\
\text { das situaçbes }\end{array}$ & ـ & ـ \\
\hline $\begin{array}{l}\text { Aprendizagem } \\
\text { continua }\end{array}$ & ـ & ـ \\
\hline $\begin{array}{l}\text { Metodologia } \\
\text { de trabalho }\end{array}$ & ـ & ـ \\
\hline Dinamismo & ـ & ـ \\
\hline $\begin{array}{l}\text { Organizaçăo } \\
\text { pessoal }\end{array}$ & - & ـ \\
\hline $\begin{array}{l}\text { Capacidade } \\
\text { de iniciativa }\end{array}$ & ـ & ـ \\
\hline $\begin{array}{l}\text { Fundamentaçăo } \\
\text { de decisōes }\end{array}$ & ـ & ـ \\
\hline $\begin{array}{l}\text { Definiçắo de } \\
\text { objectivos }\end{array}$ & ـ & ـ \\
\hline Criatividade & ـ & ـ \\
\hline
\end{tabular}


190 Margarida M. Pinheiro, Cláudia S. Sarrico \& Rui A. Santiago

$7 / 8$

\begin{tabular}{|c|c|c|}
\hline \multirow[t]{2}{*}{ Dominio } & $\begin{array}{l}\text { a) o grau de importância ou năo importância } \\
\text { que atribui a cada domínio na construçâao do } \\
\text { perfil dum diplomado. }\end{array}$ & $\begin{array}{l}\text { b) se a metodologia seguida na disciplina } \\
\text { de Projecto Profissional foi determinante } \\
\text { ou näo fol determinante na obtençăo desse } \\
\text { domínio. }\end{array}$ \\
\hline & \multicolumn{2}{|c|}{ (Escreva o algarismo que melhor se adequa à sua apreciaçäo) } \\
\hline $\begin{array}{l}\text { Capacidade } \\
\text { de sintese }\end{array}$ & $\smile$ & ـ \\
\hline $\begin{array}{l}\text { Planificaçấo de } \\
\text { tarefas }\end{array}$ & ـ & $\smile$ \\
\hline $\begin{array}{l}\text { Gestâo do } \\
\text { tempo }\end{array}$ & $\smile$ & $\smile$ \\
\hline $\begin{array}{l}\text { Análise } \\
\text { critica }\end{array}$ & 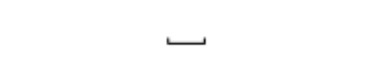 & $\smile$ \\
\hline $\begin{array}{c}\text { Comunicaçẩo } \\
\text { oral }\end{array}$ & 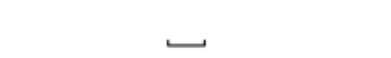 & ـ \\
\hline $\begin{array}{c}\text { Comunicaçâo } \\
\text { escrita }\end{array}$ & 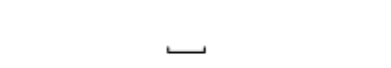 & $\smile$ \\
\hline $\begin{array}{l}\text { Confrontaçấo } \\
\text { de opinióes }\end{array}$ & 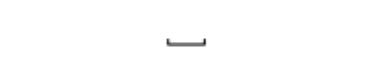 & ـ \\
\hline $\begin{array}{l}\text { Flexibilidade a } \\
\text { mudanças }\end{array}$ & ـ & ـ \\
\hline $\begin{array}{c}\text { Relaçóes } \\
\text { interpessoais }\end{array}$ & $\smile$ & $\smile$ \\
\hline $\begin{array}{l}\text { Capacidade } \\
\text { de liderança }\end{array}$ & 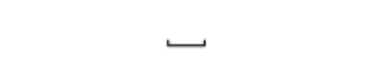 & 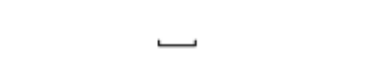 \\
\hline $\begin{array}{l}\text { Trabalho } \\
\text { em equipa }\end{array}$ & ـ & 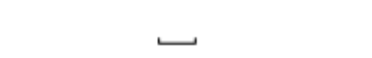 \\
\hline \multicolumn{3}{|c|}{ Caso tenha respondido "Nunca traba hei na área se contabilidade" na questăo 7. passe agora à questão 13.} \\
\hline $\begin{array}{l}\text { Visão ética } \\
\text { da profissão }\end{array}$ & $\smile$ & $\smile$ \\
\hline $\begin{array}{l}\text { Visấ da realidade } \\
\text { profissional futura }\end{array}$ & $\smile$ & $\smile$ \\
\hline $\begin{array}{l}\text { Resoluçäa de } \\
\text { problemas } \\
\text { profissionais }\end{array}$ & 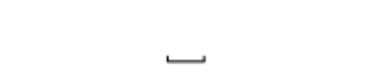 & ש \\
\hline
\end{tabular}

|| || || || || || || || ||| || 
13. As questões seguintes pretendem saber que avaliaçăo faz das suas motivaçőes e dos seus desempenhos, em funçăo da metodologia seguida na disciplina de Projecto Profissional. Indique o seu grau de concordância ou năo concordância com cada uma das afirmaçōes que se seguem, utilizando a escala de respostas

$5=$ de acordo

$3=$ nem de acordo nem em desacordo

$2=$ parcialmente em desacordo incentiva-me a desenvolver o meu sentido de autonomia.

(preencha o circulo que melhor exprime a sua opinialo)

$\begin{array}{lllll}1 & 2 & 3 & 4 & 5 \\ 0 & 0 & 0 & 0 & 0\end{array}$

13.2 A metodologia seguida na disciplina de Projecto Profissional

00000

motiva-me para uma aprendizagem permanente.

13.3 A metodologia seguida na disciplina de Projecto Profissional

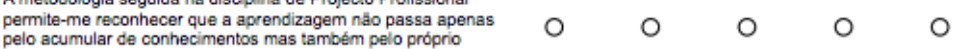
processo de os adquirir.

13.4 A metodologia seguida na disciplina de Projecto Profissional incentiva a minha capacidade de iniciativa.

13.5 A metodologia seguida na disciplina de Projecto Profissiona entre os connecimentos teórioos e as suas aplicaçoes práticas.

Obrigada pela sua participação. 